\title{
Neuronal lineages derived from the nerve-associated Schwann cell precursors
}

\author{
Polina Kameneva ${ }^{1}\left(\mathbb{D} \cdot\right.$ Maria Eleni Kastriti ${ }^{1,2} \cdot$ Igor Adameyko $^{1,2}$ (])
}

Received: 18 May 2020 / Revised: 18 May 2020 / Accepted: 22 July 2020 / Published online: 3 August 2020

(c) The Author(s) 2020

\begin{abstract}
For a long time, neurogenic placodes and migratory neural crest cells were considered the immediate sources building neurons of peripheral nervous system. Recently, a number of discoveries revealed the existence of another progenitor type-a nerve-associated multipotent Schwann cell precursors (SCPs) building enteric and parasympathetic neurons as well as neuroendocrine chromaffin cells. SCPs are neural crest-derived and are similar to the crest cells by their markers and differentiation potential. Such similarities, but also considerable differences, raise many questions pertaining to the medical side, fundamental developmental biology and evolution. Here, we discuss the genesis of Schwann cell precursors, their role in building peripheral neural structures and ponder on their role in the origin in congenial diseases associated with peripheral nervous systems.
\end{abstract}

Keywords Schwann cell precursors · Peripheral nervous system · Chromaffin cells · Enteric nervous system · Neuroblastoma $\cdot$ Hirschsprung disease

\section{Introduction}

Embryonic Schwann cell precursors (SCPs) are known as a progenitor population for myelinating and non-myelinating mature Schwann cells (SCs) covering the adult nerves. Indeed, generation of mature SCs can be seen as a wellknown and canonical function of SCPs, which originate from neural crest cells (NCCs), a highly migratory and multipotent cell population that gives rise to many cell types in the body $[1,2]$. During NCCs migration, a portion of the cells settles on the outgrowing sensory and motor peripheral nerves to become nerve-associated SCPs. SCPs express ERBB2/3 receptors, which recognize the ligand NRG1 on the surface of axons. This signaling pathway is necessary for the migration of SCPs along nerves as well as for the survival of SCPs and, indirectly, motor and sensory neurons (reviewed in [3]). In the case of Erbb2/3 or $\mathrm{Nrgl}$ deficient mice, the ventral migration of the NCCs is disturbed, and,

Igor Adameyko

igor.adameyko@ki.se

1 Department of Physiology and Pharmacology, Karolinska Institute, Stockholm 171 77, Sweden

2 Department of Molecular Neurosciences, Center for Brain Research, Medical University Vienna, Vienna 1090, Austria consequently, the sympathetic chain ganglia are hypoplastic - a finding reproduced in zebrafish [4, 5]. In these mice, SCPs are depleted from the motor and sensory nerves, which in turn degenerate in the absence of SCPs during late stages of embryonic development [6]. ERBB2/3-NRG1 signaling pathway additionally plays a role in differentiation of SCPs into myelinating and non-myelinating SCs. Large-diameter axons, which provide higher levels of NRG1 to SCPs, direct their differentiation towards myelinating SC, whereas the small-diameter axons become ensheathed into Remak bundles by non-myelinating SC $[7,8]$.

The story of the SCP origin starts with NCC migration, which is happening between E8.5 and E10.5 in the mouse, with SOX $10^{+}$NCCs taking different routes to their final and diverse destinations within the developing embryo. Around E9-9.5 and onwards, NCCs migrating next to the neural tube towards the dorsal aorta start to build the sympathetic chain and, with a slight delay, sensory neurons of the dorsal root ganglia. At the same time, the first motor axons start extending from the ventral portion of the neural tube. SCPs settle on these emerging autonomic, sensory and motor nerves to be guided to different tissues and organs of the developing vertebrate embryo. Recently, numerous studies recognized an unexpectedly broad developmental potential of SCPs in addition to their canonical role in generation of adult SC. 
The realization of such differentiation potential turned out to be dependent on a particular region, providing local tissues with necessary cell types [9]. Indeed, one of the early studies revealed that melanocytes (pigmented cells) largely originate from SCPs associated with the sensory innervation of the skin [10]. Lineage tracing experiments in mouse and chick embryos validated SCP-dependent origin of a large proportion of skin and hair follicle melanocytes. In zebrafish, post-neural crest progenitors residing in dorsal root ganglia and associated with peripheral nerves are also capable of producing melanocytes especially during metamorphosis [11]. These fish-specific $\mathrm{FOXD}^{+} / \mathrm{SOX} 10^{+}$peripheral ganglia-associated cells might be considered homologous to the amniote SCPs [12].

Over the last decade, the emerging research on SCP multipotency clarified that SCPs give rise to a broad spectrum of cell types including parasympathetic neurons [13, 14], neurons of the enteric nervous system [15-17], chromaffin cells of adrenal medulla and extra-adrenal chromaffin organ of Zuckerkandl [18, 19], a portion of sympathetic neurons in lower trunk paraganglia [19] and glomus cells of the carotid body oxygen-sensing organ [20]. When it comes to derivatives of non-neural nature, SCP-dependent origin was confirmed for endoneural fibroblasts [21], mesenchymal stem cells of bone marrow [22], dental mesenchymal stem cells [23] and some chondrocytes [24]. These discoveries led to reconsidering SCPs as a multipotent population capable of producing seemingly unrelated cell types.

Taking in account all these findings, it might be hypothesized that peripheral neurogenesis has been partitioned by the evolution to either NCCs or SCPs operating as major neurogenic sources at the body periphery. The question that arises is why some neuronal populations are not generated directly by the migratory crest as in the case of sensory and sympathetic neurons. For instance, one of the reasons can be the location of the gangliogenesis in relation to the neural tube as well as the timing of neurogenesis. Dorsal root ganglia and sympathetic chain originate directly from NCCs at early stages and are located in a close proximity to the neural tube, because the embryo is still compact at this stage. At the same time, parasympathetic ganglia or the parts of enteric nervous system develop at a larger distance from dorsal neural tube, when the embryo undergoes intense growth at later, post-NCC stages. Besides, parasympathetic and enteric neurons chronologically appear in correlation with the development and growth of the organs they are going to innervate. The timing of the emergence of such structures can vary and include late stages of development-way beyond the NCC migration stage. As the embryo might be too large for the efficient migration and navigation of the crest cells, there might be a need for the long-lasting local neural crest cell-like source. This role is perfectly performed by the nerve-associated SCPs. The neuronal projections extending towards developing internal organs ensure the precision and efficiency of the SCP delivery [25].

Finally, instead of discussing why NCCs do not give rise to some neuronal populations via active migration, we might suggest the evolutionary concept, where neural crest dispersal is achieved via nerve-assisted delivery. Quite surprisingly, we can propose that the active migration of the NCCs can be, in fact, a later evolutionary acquisition relying on elaboration of complex and diverse navigation programs. At the same time, the basic ancient way of delivering progenitors might be rather represented by the SCP-like nerve-associated transportation route. Such nerve-assisted delivery of progenitors does not require the individualization of the navigation programs, which are necessary for the targeted active migration of progenitors to the sites, where specific neural and mesenchymal derivatives should form. The nerves, which possess ancient navigation tactics, can mediate all pathfinding and subsequently target all necessary regions of the body bringing multipotent cells on their surface. In places where needed, SCPs can detach and convert into other fates, whereas the rest will differentiate into mature SCs. Some support for such ideas comes from the recent discovery of the nerve-assisted delivery of SCPs to the lamprey gut, where these SCPs give rise to the enteric nervous system [26]. This suggests the ancient and widespread conserved role of SCPs being intermediates between the crest and the definitive cell type. Thus, SCPs might represent the "evolutionary early version" of the migratory neural crest and serve as a universal tool for the delivery of multipotent progenitors from the central nervous system to the body periphery.

\section{The developmental origin and basis of fate potential of SCPs}

Even though it is clear that SCPs are neural crest-derived, the molecular mechanisms driving a portion of freely migrating NCCs into SCP-fate are not fully elucidated. This missing knowledge is fundamental to understand the mechanism driving the fate segregation towards nerve-associated SCPs prior to their differentiation towards different peripheral neuronal populations.

In an effort to address this key question, researchers used single-cell RNA sequencing (scRNA-seq) coupled to computational analysis of RNA velocity [25] on several stages of early murine neural crest development. The resulting model revealed that cell fate decisions in NCCs occur in a binary restrictive mode, where cells make a choice between two competing fate-specific programs at a time [27]. According to this model, fate decisions in the neural crest proceed via three distinct stages: initial co-activation of competing transcriptional programs, gradual biasing towards one of 
the programs under the pressure of intrinsic and extrinsic factors, followed by a commitment phase, when one of the programs dominates.

Soldatov and co-authors detected the presence of fatebiasing factors already during delamination, which suggests that the choice of a final fate might be influenced already at the level of the neural tube [27]. As NCCs delaminate and progress towards a migratory phase, one of the bifurcations provides the alternatives between sensory neuronal and common progenitors of autonomic and mesenchymal branches including SCP fate. Previous studies had revealed the role of DELTA-NOTCH signaling in the process of pro-neurogenic and non-neurogenic fate choice. Neuronal progenitors express DELTA-like1 signal, which acts on a $\mathrm{NOTCH}^{+}$adjacent cells and inhibits their neuronal program, which leads them to adopting the glial program. This process, known as lateral inhibition, results in a salt-and-pepper induction pattern of the neuronal and glial cell types in dorsal root ganglia $[28,29]$. The ablation of Notch from migrating NCCs causes severe hypoplasia of dorsal root ganglia and disturbed neuroglial balance [30].

According to Soldatov et al., the second major fate split between neuroblasts and SCPs occurs within the autonomic nervous system domain. The authors of this study addressed the position and transcriptional signature of the neural crest subpopulation committing into SCPs, with Zfp488, Mstn, Gpr17, $M p z$ and other genes associated with this process. The position of forming SCPs among diversifying crest populations on the developmental trajectory has been verified by superimposing the more stagewise-advanced dataset containing unambiguous SCP cells. The commitment to the SCP fate might be triggered by the physical interaction with the nerves, DELTA-NOTCH signaling and higher levels of anchored NRG1 provided by the neurites quickly emerging from neuronal somas at this developmental stage. According to scRNA-seq data, all migratory NCCs express the NRG1 receptor $E r b b 2 / 3$, which means that they must rely on some soluble NRG1 produced by a local source. This hypothesis is strengthened by the fact that in Erbb3 knockout mice, there is a general neural crest deficiency both in the trunk and cranial parts [31].

Surprisingly, satellite glial cells forming inside of the ganglia are not sensitive to NRG1 signaling: in Erbb2/3 knockouts they stay largely unaffected [10]. This suggests important differences in commitment tactics in gangliadwelling populations of peripheral glial cells. Even though it is increasingly clear that fate commitment in the SCP domain might be driven through extracellular signaling such as DELTA/NOTCH and NRG1/ERBB2/3, uncovering distinctions between developing satellite glial cells and SCPs along the outgrowing nerves is technically problematic. Despite the fact that Smart-seq2 single-cell transcriptomic data provide a good resource for studying molecular mechanisms of NCC commitment to the SCP fate, the cell numbers generated so far are not yet sufficient for the reliable analysis of fine transcriptional changes during SCP formation timeline. Such analysis is further complicated due to the extraordinary similarity of the molecular signature characterizing SCPs and migratory NCCs [27].

The maintenance of such similarity between NCCs and SCPs might hint us on the question about the molecular reasons of SCP multipotency. According to the existing data, SCPs and NCCs share major components of their gene regulatory networks, such as the transcriptional factors SOX10 and FOXD3. Research has uncovered similar gene expression regulation tactics between NCCs and SCPs, in particular in relation to regulation of Sox10 expression, which is essential for NCC and SCP survival and differentiation [32]. Recent studies showed that maintenance of Sox10 expression in NCCs and their differentiation towards SCPs as well as survival of SCPs and normal myelination additionally involve regulation by histone deacetylases $\mathrm{HDAC} 1 / 2$ [33-36]. HDAC1/2 interact with the Sox 10 enhancer regions U1/MCS7 and U3/MCS4 during the development of NCCs, SCPs and their glial fates. To maintain Sox10 expression, HDAC2 activates MCS4 and Fabp 7 indirectly and the $P O$ promoter in a direct manner, further enhancing the expression of the glial program $[33,37]$. NCCs and SCPs share the transcription factors PAX3, AP2A, and SOX10, which bind to the U3/MCS4 enhancer. Therefore, SOX10 is involved in the control of its own expression, as well as being finely regulated by other transcriptional factors during the specification of SCPs [38]. The other common transcriptional factor found in both NCCs and SCPs, FOXD3, is indispensable for the maintenance of the migratory phenotype of NCCs and SCPs. Downregulation of FOXD3 plays an important role in the specification of melanocytes from both types of precursor cells [10, 39]. Therefore, the intimate relationships between SCPs and neuronal processes as well as survival of SCPs is established under the transcriptional control of a gene regulatory network shared with NCCs to a large extent.

Overall, the NCC-like multipotency of SCPs might reside in a common transcriptional code. However, the question of why SCPs give rise to particular derivatives in specific locations stays largely unexplored. We expect that this question will be addressed in the near future with the expansion of spatial transcriptomic techniques.

\section{SCP-dependent origin of parasympathetic and some sympathetic neurons}

All daily functions in mammals result from the function of the two components of the peripheral nervous system: the parasympathetic and sympathetic divisions. The 
parasympathetic division of the peripheral nervous system is responsible for the so called "rest and digest" functions including salivation, digestion, urination and others. In contrast to this, the sympathetic system is responsible for the "fight or flight" response in periods of stress which includes increased heart rate, release of glucose into the bloodstream by the liver, dilated bronchioles facilitating increased breathing and alike. The important differences between parasympathetic and sympathetic neurons include neurotransmitter systems and relations to the location of the preganglionic fibers arriving from the central nervous system. Specifically, cholinergic parasympathetic ganglia are typically found within the target organ and receive preganglionic innervation via long axonal projections from the spinal cord. Contrary to this, sympathetic neurons are found further away from their targets to which they project longer axons as compared to parasympathetic neurons. Neurons of the sympathetic ganglia predominantly use norepinephrine as a neurotransmitter.

However, it is important to mention that it has been made increasingly clear that neurotransmitter expression alone is not enough to discriminate between parasympathetic and sympathetic ganglia. There are examples of cholinergic sympathetic innervation of sweat glands and periosteum also in line with the recent identification of cholinergic neuronal subtypes within stellate and thoracic sympathetic ganglia as revealed in a single-cell transcriptomic study [40-42].

Parasympathetic neurons are grouped into ganglia located in all parts of the body except for the limbs and other extremities. Particularly in the cranial and thoracic region of the body, parasympathetic neurons form the cranial ciliary, pterygopalatine, lingual, otic, submandibular ganglia and cardiac parasympathetic ganglia, all of which receive preganglionic innervation from preganglionic neurons of the brainstem through projecting cranial nerves [43, 44].

Early transplantation experiments and DiI tracing in chick embryos focusing on cranial regions had concluded that parasympathetic neurons originate from the migratory NCCs $[45,46]$. However, soon it appeared obvious that active migration of cranial and trunk NCCs ceases to exist at E10 stage in mouse as by this time and all $\mathrm{SOX} 10^{+}$cells found to be nerve-associated [31]. Induction of genetic recombination in Sox 10-CreER ${ }^{T 2} /$ Rosa26 $^{Y F P}$ embryos at E11.5, a developmental point at which all SOX $10^{+}$cells are SCPs found on the nerves, labelled nearly all neurons in parasympathetic cranial ganglia and substantial part of caudal sympathetic ganglia analysed at E17.5 [13, 19]. Additionally, ASCL1 ${ }^{+}$/ $\mathrm{PHOX}_{2 \mathrm{~B}^{+}}$cells, which represent committed parasympathetic progenitors, were revealed in close contact with preganglionic nerve fibers already at E12.5. At the same time, these nerve-associated pro-neural cells co-expressed SCP markers Sox 10 and Erbb2/3 indicating that these progenitors are in transition from SCPs fate to parasympathetic fate at this developmental stage.
Additionally, according to Espinosa-Medina and coauthors, SOX $10^{+}$SCPs found along the cranial nerves initially activate the expression of Phox $2 b$ during their migration towards the future locations of the parasympathetic ganglia. Then, upon their arrival to the location, where the ganglia will form, they activate the expression of the proneurogenic gene Ascll. Shortly after their dissociation from the nerves and an onset of ganglia formation, the expression of Sox 10 and Phox $2 b$ becomes mutually exclusive. SOX $10^{+}$ cells that remain associated with the axons lose expression of pro-neurogenic markers and commit to the Schwann cell lineage (Fig. 1) [14].

Apart from the lineage tracing experiments, a series of loss-of-function studies validated the SCP-based origin of parasympathetic neurons. For instance, $\operatorname{Ret}^{-/-}$mice miss specific preganglionic visceral motor nerves (greater superficial petrosal and Jacobson's nerves typically targeting developing parasympathetic ganglia in the head). The loss of these preganglionic nerves was associated with the absence of the corresponding parasympathetic ganglia they normally innervate, whereas the ganglia associated with the chorda tympani and oculomotor nerves developed normally, since these nerves are not affected by the loss of Ret [13]. Consistently, ablation of cranial nerves in Neurog $2^{-/-}$and Neurog $1^{-/} ;$Neurog $2^{-/-}$mice showed a conceptually similar result, since the mutant embryos developed deficiencies of the major preganglionic parasympathetic nerves in the face and heart [14]. Furthermore, Erbb3 ${ }^{-/-}$mice are characterized by the absence of SOX $10^{+}$nerve-associated SCPs and are characterized by the absence of parasympathetic neurons. Finally, the analysis of $\mathrm{Ascll}^{-1-}$ mice combined with tracing of the Ascll lineage in Ascll-CreER ${ }^{T 2}$ embryos concluded that SCPs were not able to differentiate towards neurons due to the lack of this proneural gene, and, instead, Ascll-deficient SCPs populated the preganglionic nerves while maintaining the expression of glial markers (SOX10, ERBB3, SOX2 and BFABP) [13]. Clonal lineage tracing analysis of SCPs contributing to parasympathetic neurons using a Confetti reporter revealed that a single SCP cell gives rise only to 2.5 parasympathetic neurons and 6-8 local glial cells on average, which suggests that large numbers of SCPs must be recruited to build parasympathetic ganglia, often hosting hundreds of neurons [13]. This observation renders SCPs as progenitors with limited expansion potential unlike classical stem cells with transiently amplifying cell cascade. Thus, local preganglionic nerves serve as important breeding centers ensuring sufficient numbers of SCPs, which allows the local preganglionic innervation to control the size of future parasympathetic ganglia.

Contrary to the case of cranial and cardiac parasympathetic ganglia, lineage tracing experiments in mice have shown that the vast majority of sympathetic neurons originates directly from the migratory NCCs. However, a small 


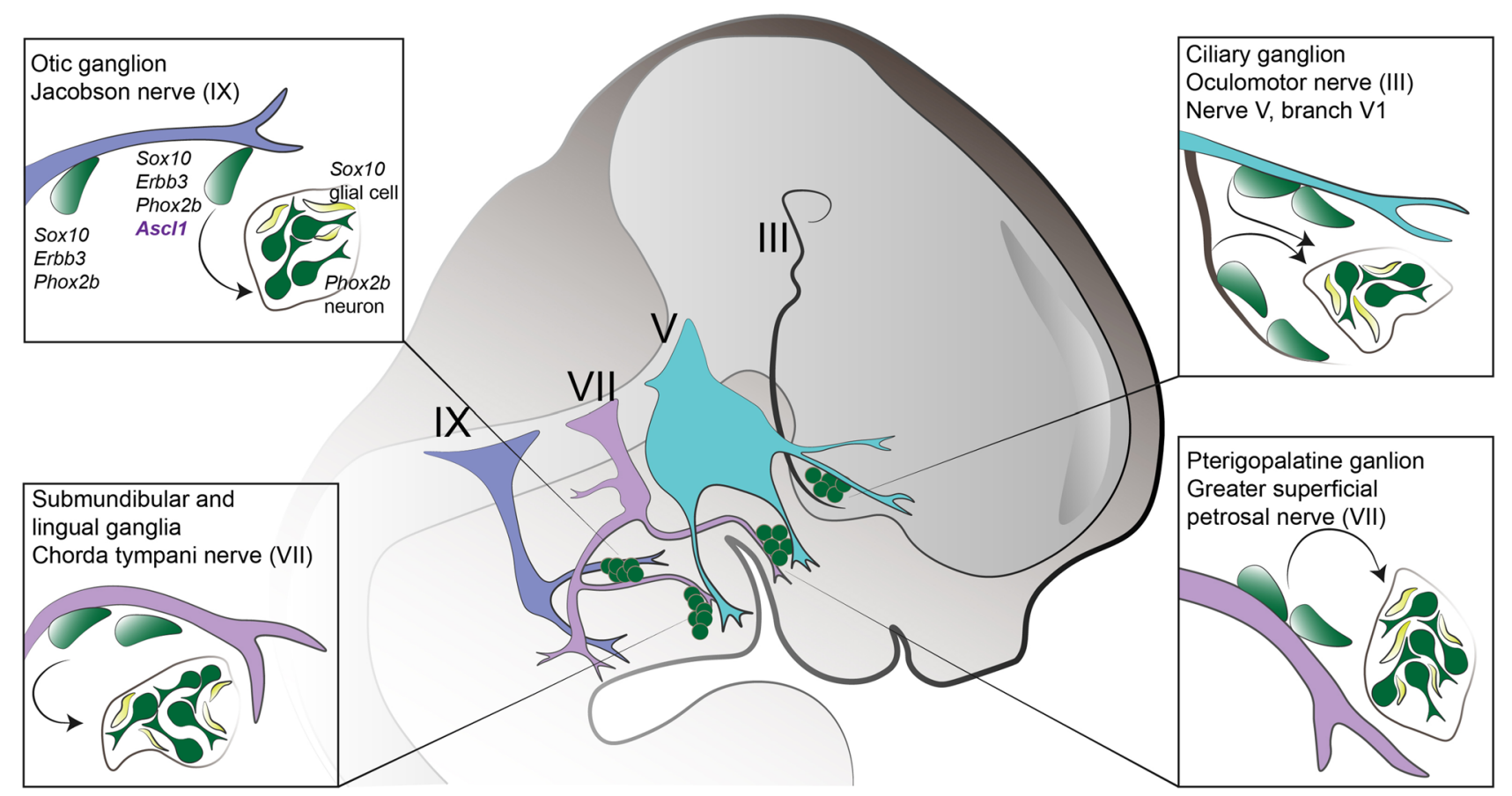

Fig. 1 Neurons in parasympathetic ganglia in the cranial region: otic, submandibular, lingual, ciliary, and pterygopalatine originate from SCPs. SCPs first upregulate PHOX2B upon reaching the distal

proportion of sympathetic neurons at the posterior part of the sympathetic chain appear to have a SCP origin [18]. Therefore, the possibility that SCPs and satellite glial cells indeed give rise to a fraction of sympathetic neuroblasts persists. In support of this fact, sympathetic paraganglia located in the vicinity of the developing adrenal gland and the organ of Zuckerkandl contain much higher proportion of SCP-derived sympathetic neurons-up to $13 \%$ and more if normalized for the recombination efficiency [19].

Until recently, lower trunk pelvic ganglia innervating the rectum, bladder and genitals were considered parasympathetic. This conclusion was supported by the early assumptions about sacral preganglionic neurons resembling preganglionic brainstem neurons in terms of their localization and pharmacology (being mainly cholinergic) and the fact that the function of said organs (rectum, bladder, genitals) was believed to be necessarily controlled by antagonistic sympathetic and parasympathetic ganglia residing at upper lumbar (sympathetic preganglionic innervation) vs lower lumbar and sacral levels (parasympathetic preganglionic innervation) of the spinal cord [47-49]. However, a recent study from Brunet lab challenged this idea by showing that sacral preganglionic neurons innervating pelvic ganglia have a pro-sympathetic profile that does not differ from thoracic sympathetic preganglionic neurons that innervate the sympathetic chain [50]. Specifically, the study showed that the generation of sacral preganglionic neurons depends on parts of the nerves, and upregulate ASCL1 and once the ganglia are formed the expression of SOX10 and PHOX2B becomes mutually exclusively restricted to glial and neuronal cell types respectively

the Olig2 gene, similarly to thoracic preganglionic neurons innervating the sympathetic ganglia and in contrast to the Phox $2 b$-dependance of preganglionic neurons innervating parasympathetic ganglia. Additionally, the team showed that ablation of the spinal preganglionic motor neurons did not affect the generation of these pelvic ganglia, proving that they are largely generated from migratory NCCs, similarly to most sympathetic neurons. This embryological argument helped to revisit the original classification of these ganglia formerly known as parasympathetic, as one of the main reasons for the old classification was the use of acetylcholine as their main neurotransmitter. However, as mentioned before, a number of studies have shown that there are cases of sympathetic ganglia using acetylcholine as the main neurotransmitter [40-42]. After the discovery of specifics of pelvic ganglia development, the debates about attributing them to sympathetic, parasympathetic systems or mixed ganglia are still very active $[47,48,51]$.

\section{Chromaffin cells originate from SCPs}

Chromaffin cells are neuroendocrine cells that are responsible for the release of catecholaminergic hormones into the blood flow to trigger the "fight-or-fly" response. These cells belong to the sympathetic division of the peripheral nervous system and largely resemble sympathetic neurons. 
Chromaffin cells differentiate under the control of a transcriptional cascade similar to sympathetic neurons (discussed in more detail below) and use many of the neurotransmitters typical for sympathetic neurons. However, chromaffin cells do not extend neuronal processes, and neither possess classic synaptic machinery. At the same time, they are capable of forming neuro-glandular synapses [52, 53].

There are two major locations of chromaffin cells: the medullary region of the adrenal gland (intra-adrenal) and the transient organ of Zuckerkandl (extra-adrenal). Chromaffin cells of the organ of Zuckerkandl appear in close proximity to the cells of the superior mesenteric ganglion and other local paraganglia. In contrast to this, intra-adrenal chromaffin cells are isolated from the environment by the surrounding adrenal cortex. Embryonic and perinatal chromaffin cells perform an additional function of oxygensensing similarly to glomus cells in carotid bodies. This function is believed to be necessary for the first breath initiation and primary adaptation to the extra-uterine life. Chromaffin cells abandon oxygen-sensing function within the first week of postnatal development $[54,55]$.

The primordium of the adrenal gland starts to coalesce at E11.5 in mouse-long after NCCs complete their migration in this region at E9.5-E10. Previous studies firmly established the neural crest-derived origin of chromaffin cells. Specifically, NCCs between the 18th and 24th somite contributed to formation of adrenal medulla, as shown by heterospecific transplantation of quail neural tube rudiments into developing chick embryo. Subsequently, the quail-specific nucleus structure was identified in chromaffin cells of chick embryos (Fig. 2a) [56, 57]. Morphogens produced by the dorsal aorta are important for proper migration and differentiation of migrating NCCs towards the sympatho-adrenal fate. Among the dorsal aorta-derived morphogens, BMPs do not directly attract the sympathoadrenal progenitors toward the area of sympathetic ganglia and adrenal gland formation but instead initiate the expression of SDF1 and NRG1 by the para-aortic mesenchyme, which in turn act as chemoattractants for precursor cells. Moreover, BMPs were thought to play a role in the segregation of sympathetic and chromaffin fate, by earlier deactivation of BMP receptors family Smad in sympathoblasts, but prolonged maintenance in chromaffin cells [58]. Upon the migration of the sympatho-adrenal progenitors towards the site of a future primordium, the expression of major transcriptional factors is initiated: Mashl/Cashl, Phox2A/B, Hand 2, Gata2/3 and Insml (reviewed in [59]).

Previously, adrenal chromaffin cells and sympathetic ganglia were thought to develop from a common population of NCCs based on DiI applications for lineage tracing and numerous in vitro studies directing NCC differentiation into chromaffin and sympathetic neurons upon NGF treatment
$[60,61]$. The fate segregation was proposed to depend on glucocorticoids and nerve growth factor (NGF) based on the in vitro studies [61]. Later in vivo experiments ensured that glucocorticoids play an important role for the postnatal survival of chromaffin cells and the acquisition of PNMT by some chromaffin cells, but not for chromaffin vs sympathetic fate segregation $[62,63]$.

The growing block of evidence points to the fact that the precursors of sympathoblasts of the sympathetic ganglia and chromaffin cells are different. For example, chromaffin cells and sympathoblasts differentially express markers of neuronal lineage. Neurofilaments and tyrosine hydroxylase first start to be expressed in sympathoblasts and later at chromaffin cells [64]. The technological advancement in engineering transgenic mice models that allowed cell lineage tracing and lineage specific gene ablation provided important insight into the development of chromaffin cells (Fig. 2b).

According to recent results by Furlan and co-authors, the lineage split between sympathoblasts and chromaffin cells occurs in the vicinity of the adrenal glands before the formation of first chromaffin structures. Lineage tracing with the Ret-CreER ${ }^{T 2}$ strain from E9.5 to E11.5 clearly showed that $\mathrm{RET}^{+}$cells give rise to the majority sympathoblasts in paravertebral and suprarenal ganglia, and to only a few chromaffin cells of the adrenal gland or Zuckerkandl organ $[18,19]$. In line with these results, lineage tracing using Ascll-CreER ${ }^{T 2}$ demonstrated that $\mathrm{ASCL}^{+}{ }^{+}$progenitor cells generate chromaffin cells, but not sympathoblasts, if recombination is induced at E10.5 (Fig. 3). These results were further supported by SCP- and neural crest-specific inducible Cre lines Sox10-CreER ${ }^{T 2}$ and Plpl-CreER ${ }^{T 2}$, which revealed a SCP-dependent origin of the majority of chromaffin cells inside of the adrenal medulla and in the organ of Zuckerkandl. In those cases, the genetic recombination resulting in cell labelling occurred after E11.5, with further evidence that labelled cells were SCPs covering preganglionic visceral motor nerves arriving to the location of developing chromaffin structures from the neural tube $[18,19]$.

In an attempt to deplete SCPs from the nerves before the onset of chromaffin cell development, Furlan and coauthors crossed Sox10-CreER ${ }^{T 2}$ mice with Rosa26 $6^{\text {DTA }}$ (diphtheria toxin) transgenic strain to induce the death of SOX $10^{+}$SCPs upon tamoxifen injection. When recombined at E11.5 and E12.5, this experiment resulted in a dramatic depletion of SCPs and chromaffin cells in adrenal medulla. Furthermore, genetic ablation of preganglionic motor nerve fibers (serving as the routes delivering SCPs to the sympatho-adrenal primordium) in $\mathrm{Hb}$-Cre; Isl ${ }^{\text {DTA }}$ embryos resulted in a substantial decrease of chromaffin cell number in both chromaffin locations (Fig. 4). Consistently, in Ascl1 ${ }^{-1-}$ mice the researchers observed the accumulation of $\mathrm{SOX} 10^{-} / \mathrm{PHOX}_{2} \mathrm{~b}^{+} / \mathrm{TH}^{-}$cells along the nerves and the developing primordium and a significant decrease of 
Fig. 2 Quail-to-chick transplantation and genetic lineage tracing as tools to discover neural crest cells and Schwann cell precursor to neuronal lineages. a quail-to-chick transplantation methodology has revealed the contribution of vagal neural crest to enteric nervous system and limbal neural crest to adrenal medulla and sympathetic chain ganglia. b generation of Cre recombinase and reporter transgenic mouse lines enabled lineage specific cell labeling and consecutive discoveries of SCPs contribution to neuronal lineages. $N T$ neural tube, $D R G$ dorsal root ganglion

\section{(a) QUAIL-to-CHICK TRANSPLANTATION}

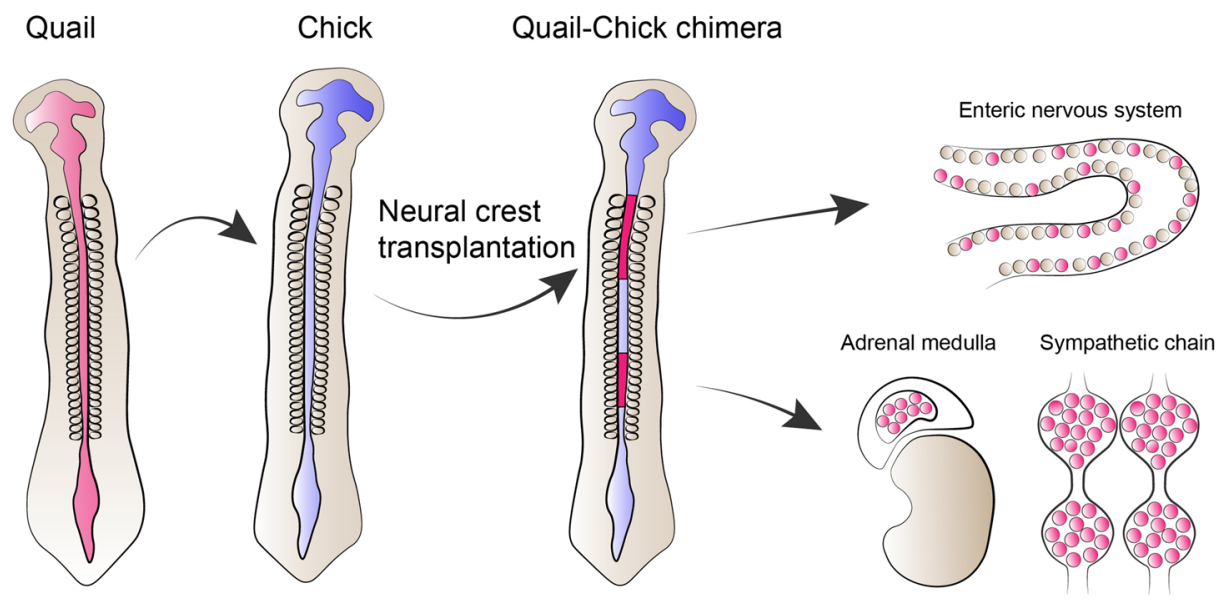

(b) GENETIC LINEAGE TRACING

From neural crest lineage

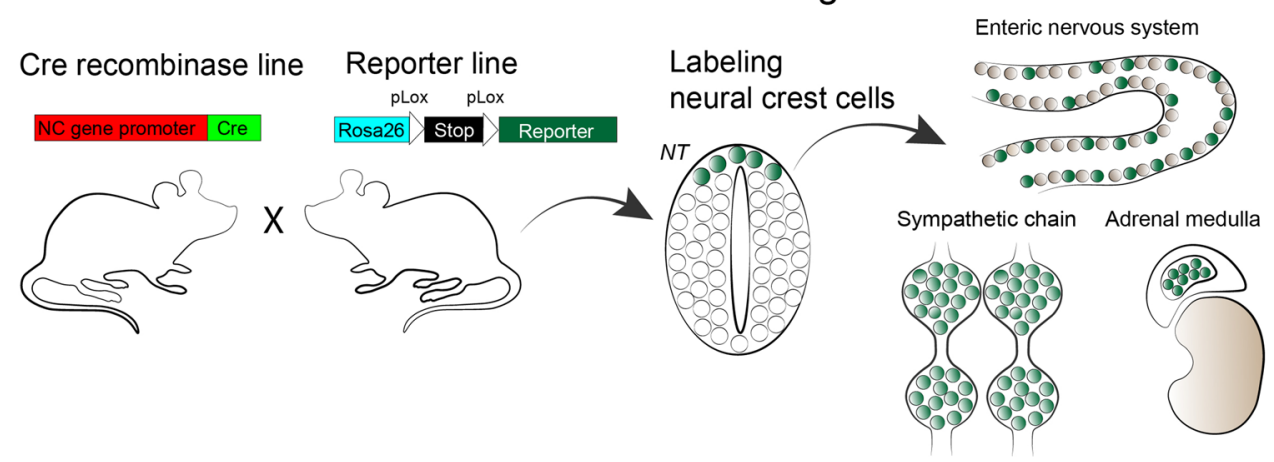

From Schwann cell precursors lineage

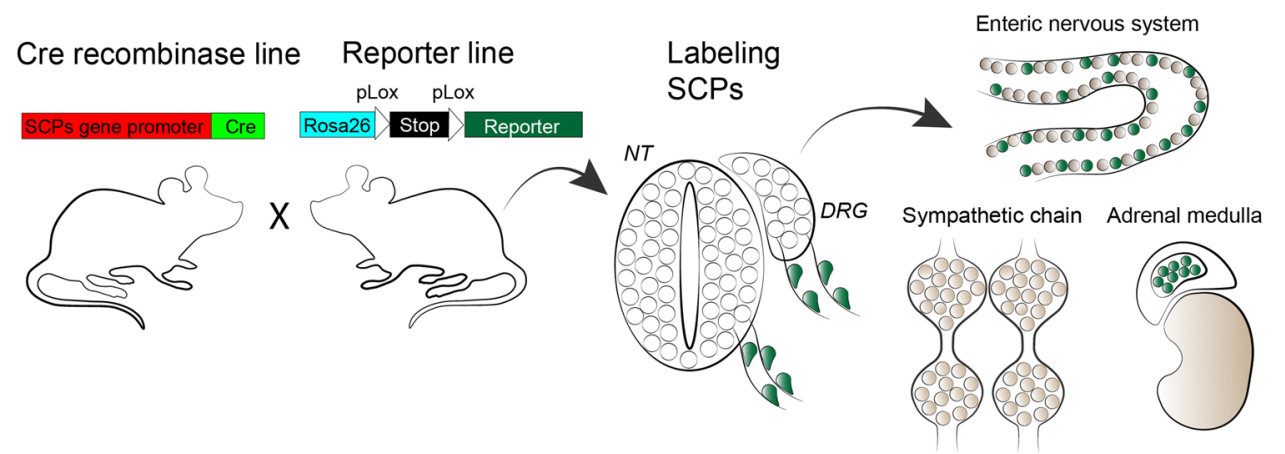

adrenal medulla and organ of Zuckerkandl chromaffin cells $[18,19]$.

In an independent chain of experiments, Lumb et al. revealed that genetic ablation of visceral motor neurons in the neural tube results in the dramatic decrease of chromaffin cells in adrenal medulla. Ablation of preganglionic motor neurons by means of Olig2-Cre mice breeding with Rosa $26^{D T A}$ strain resulted in loss of $69 \%$ of chromaffin cells in the adrenal medulla. Next, Lumb et al. showed that NRP2, a receptor to SEMA3A and SEMA3F, mediates the preganglionic visceral motor axons pathfinding towards the developing adrenal medulla. In $\mathrm{Nrp} 2^{-/-}$and Sema $3 f^{-/}$mice, axons that are normally innervating the developing adrenal medulla, abnormally innervated the urogenital ridge. Subsequently, chromaffin cells were found along the misguided axons in an aberrant location. The mis-positioning of chromaffin cells indicates the essential role of axon guidance pathways for achieving the correct anatomic location of tissues containing chromaffin cells [65]. 
Fig. 3 Inducible lineage specific tracing allows to segregate the precursor cells of sympathoblasts and chromaffin cells. a induction of Cre recombinase under the control of Ret promoter results in labeling of cells in sympathetic ganglia, with minimal contribution to chromaffin cells. $\mathbf{b}$ induction of Cre recombinase under the control of Ascll promoter as well as SCPs specific promoters Sox 10 and Plp1 results in labeling of chromaffin cells, with minimal contribution to sympathoblasts. $S G$ sympathetic ganglia, $S R G$ suprarenal ganglion, $S M G$ superior mesenteric ganglion (a) Activated at E10.5 or E11.5
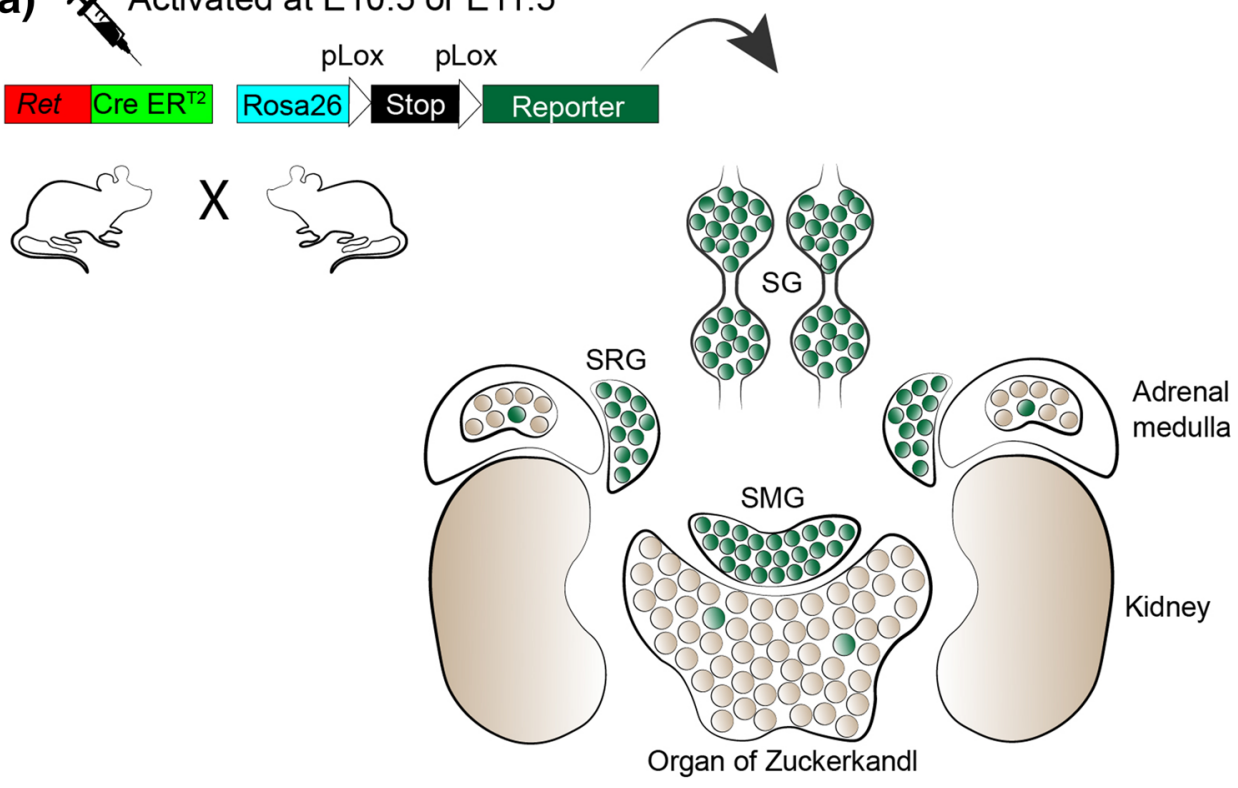

(b) Activated at E11.5

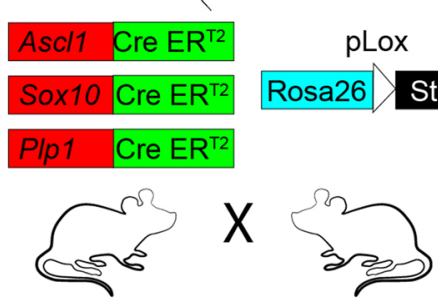

Finally, Furlan et al. performed sc-RNA seq to elucidate the cell fate transition from SCPs to chromaffin cells. When sampled at E12.5 and E13.5, SCPs, chromaffin cells and sympathoblasts form distinct clusters of cells with remarkably different molecular signatures. Some of these clusters, i.e., SCPs and chromaffin cells are connected by a "bridge cell" population with its own gene expression profile including Htr3a and other genes. The existence of such "bridge" stage indicates the captured transition of one cell type into another, further proving the SCP-derived origin of chromaffin cells. The scRNA-seq data revealed that the population of SCPs intensely proliferates and fuels the development of adrenergic chromaffin tissue. Chromaffin cells are not proliferatively active at the same stages and slowly resume proliferation only after E14.5 according to the lineage tracing analysis [18]. 


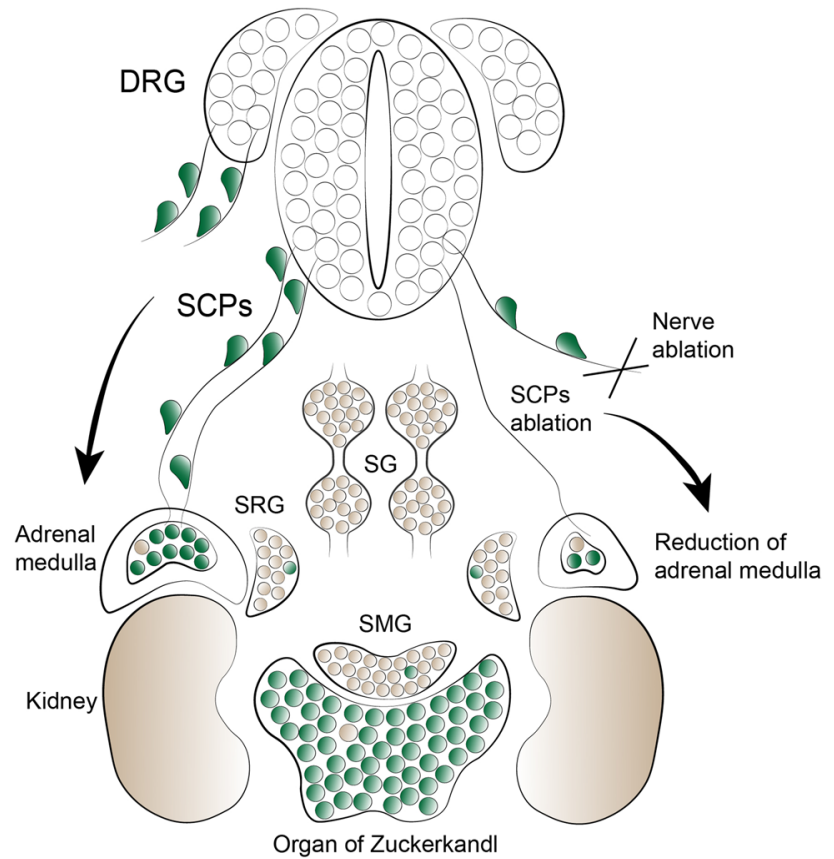

Fig. 4 Schwann cell precursors differentiate into chromaffin cells of adrenal medulla and organ of Zuckerkandl. At E11.5 in mice SCPs guided by preganglionic nerves reach the primordium of adrenal gland and differentiate in chromaffin cells. Upon nerve- or SCPablation the cells are unable to reach the adrenal gland primordium which results in reduction of the cells building the adrenal medulla. An analogous process governs the development of organ of Zuckerkandl. DRG dorsal root ganglion, SCPS Schwann cell precursors, $S G$ sympathetic ganglia, $S R G$ suprarenal ganglion, $S M G$ superior mesenteric ganglion

\section{Oxygen-sensing cells originate from SCPs}

Glomus cells of the carotid body are located at the bifurcation of the carotid artery and are primary oxygen-sensing cells in our bodies. They are responsible for mediating the respiratory response to arterial blood hypoxia and hypercapnia by releasing neurotransmitters dopamine and serotonin to the carotid sinus nerve afferents [66, 67].

Early experiments using chick-quail chimeras revealed that all cells inhabiting the carotid body are neural crestderived together with part of the carotid artery wall [68]. A more detailed investigation of carotid body growth during hypoxemic conditions revealed that $\mathrm{GFAP}^{+}$glial cells resident in the organ are the source of increased proliferation and growth [69]. Later lineage tracing experiments revealed that the carotid body has a composite origin and it is partly derived from local SCPs. When the recombination was induced in the embryos carrying SCP- and neural crest-specific Plp1-CreER ${ }^{T 2}$ at E12.5, PLP1 ${ }^{+}$progenitors gave rise up to $60 \%$ of all glomus cells in the carotid body [20]. Another portion of the carotid body originated from the neural crest-derived neuroblasts, which transiently populate the nodose ganglion. This was validated by grafting the vagal neural crest region from the $\mathrm{GFP}^{+}$transgenic donor chick embryo into the non-transgenic host embryo to monitor the cell fate later in development. After grafting, the neural crest-derived cells were first observed in the nodose ganglion closer to the carotid body. Soon after, these cells emigrated towards the carotid body forming the peripheral part of the organ. The migrated $\mathrm{GFP}^{+}$cells started to express TH and showed the presence of serotonin unlike nodose ganglion neurons [20].

\section{A significant part of the enteric nervous system is SCP-derived during embryonic and postnatal stages}

The enteric nervous system (ENS) is the largest compartment of the peripheral nervous system and is composed of two neuronal networks: the myenteric and submucosal plexus, spanning from the esophagus to stomach and intestine. The ENS is responsible for the control of intestinal motility and secretory functions (reviewed in [70]) as well as involved into complex relationships with microbiota $[71,72]$. The cell type composition of ENS is still under investigation despite significant recent progress in this direction [73-75].

Even though the colonisation of the prospective foregut starts as early as E9.5 in mouse by vagal NCCs, the ENS keeps developing during embryonic and early postnatal stages to accommodate for the growth of digestive tract. Logically, such a long span of a developmental period and following growth requires a long-lasting source of precursor cells.

The first evidence of NCCs giving rise to the cells of the ENS came from a study in which surgical removal of postotic neural crest in chick embryos was performed, leading to reduced development of ganglia in lungs, heart, esophagus and gastrointestinal tract [76]. Later experiments on chick-quail chimeras showed that vagal NCCs (somites 1-7) are precursor cells for the entire avian ENS spanning from the crop to large intestine (Fig. 5a). At the same time, sacral neural crest at the level of 28th somite gave rise to post-umbilical gut ganglion [77]. The observation of developmental dynamics disclosed that vagal NCCs first accumulate in the caudal branchial arches at E3.5 in chick and enter the foregut (including esophagus, stomach, duodenum) to migrate rostro-caudally toward the cecal-colorectal junction by E7 in chick. During later stages, sacral NCCs start migrating caudo-rostrally at E4 in chick and colonize the gut up to the level of the bile ducts in duodenum. Therefore, the avian ENS of the hindgut consists of the progenies of vagal and sacral NCCs with the increasing contribution of sacral NCCs in the rostro-caudal direction 
(a) INITIAL DISCOVERIES

$$
\begin{aligned}
& \text { First wave of neural crest cells } \\
& \text { invades the fore gut at E9.5 in mouse }
\end{aligned}
$$

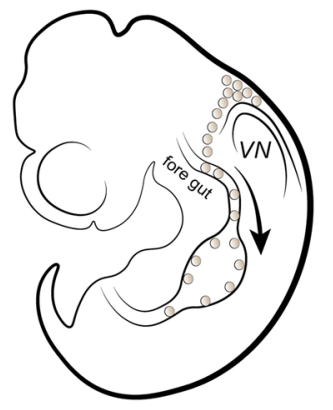

\section{(b) NEW VISION}

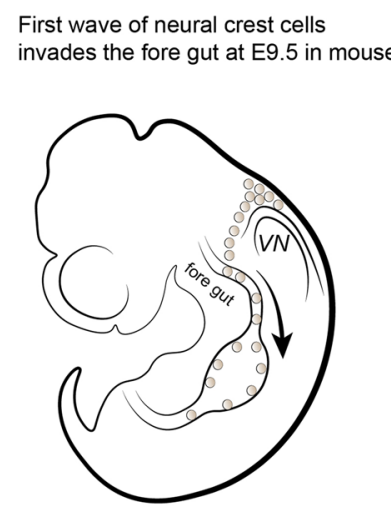

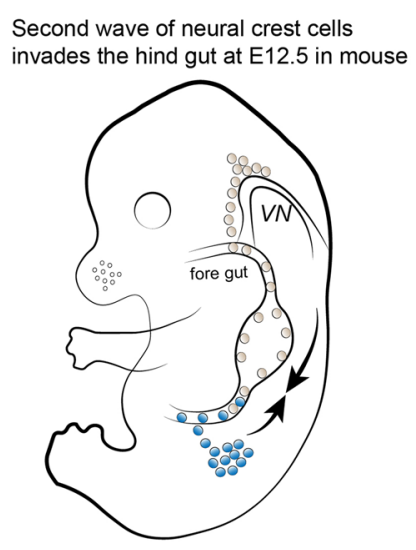

Rosto-caudal invasion is complemented by SCPs associated with vagus nerve from E11.5

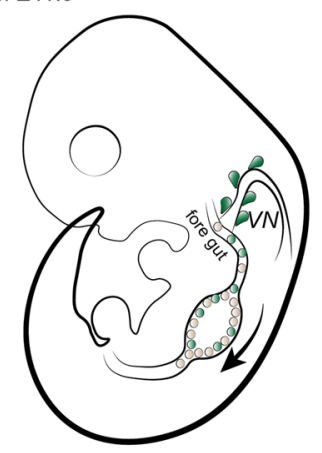

Caudo-rostral invasion is achieved by neural crest cells from E12.5

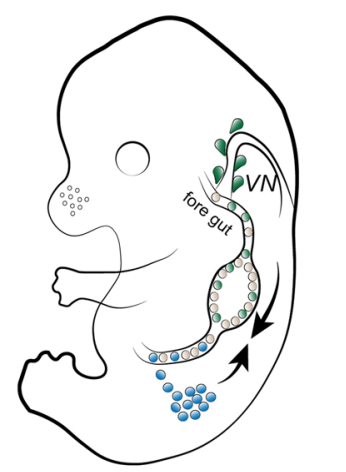

Postnatal neurogenesis in hind gut is supported by SCPs

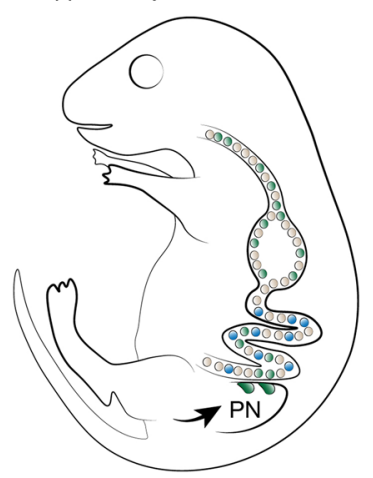

Fig. 5 Recent update in the understanding of enteric nervous system development. a initial experiments revealed that vagal neural crest contributes to the entire enteric nervous system and sacral neural crest contributes to the enteric nervous system in the most cau-

reaching $17 \%$ in myenteric plexus and $1.3 \%$ in submucosal plexus in the most caudal part of the gut [78]. The detailed study of dynamic of enteric NC migration revealed that vagal NC-derived cells migrate as a population and cellto-cell contacts are important for the propagation of the leading group of cells along the enteric mesenchyme in rostro-caudal direction [79]. Sacral NCCs have a limited potential to migrate, perhaps because of lower expression of Ret in comparison to vagal NCCs [80]. The sacral NC first forms the pelvic ganglia and only later start invading the hind portion of the gut, after the vagal NCCs have already populated it (Fig. 5a) [81] (reviewed in [82]). During the development of intrinsic gut innervation from E10.5 to E11.5, the extrinsic innervation of the intestinal wall develops, carrying high numbers of SCPs along the extrinsic nerves [83, 84].

Among the major factors playing a key role in ENS development are RET, GDNF and GFR $\alpha 1$. The receptor tyrosine kinase RET couples to GFR $\alpha 1$ in a GDNF-mediated manner to initiate downstream signaling pathways. RET/GFR $\alpha 1 /$ dal part of the gut. b late genetic manipulations in mice revealed the role of SCPs in building the enteric nervous system during embryonic and postnatal development. VN vagus nerve, $P N$ pelvic nerve, $S C P S$ Schwann cell precursors

GDNF signaling plays an important role in the development and survival of peripheral autonomic, sensory neurons as well as dopamine neurons in central nervous system. Downstream of this pathway ERK, PI3P/AKT, MAPK and JNK signaling pathways play various roles in cell survival and proliferation (reviewed in [85]). Moreover JNK, MEK and cAMP dependent cascades play critical roles in speed and directionality of the migration of ENS progenitors [86]. Mouse models lacking Ret [87-89], Gdnf [90-92] or Gfral [93] demonstrate aganglionic small and large intestine; however, none of them shows a complete lack of enteric neurons. Most importantly, vagal NCCs in these models cease their migration and undergo cell death before colonizing caudal parts of the intestine. Next, in $\mathrm{Ret}^{-/-}$and $\mathrm{Gfral}^{-/}$perinatal embryos, a few enteric neurons were found in the submucosal layer of the intestine, distal from stomach and being associated with extrinsic innervation. Such neurons were completely absent from the areas of intestine that do not have any extrinsic innervation [15]. These observations suggested that there is an additional source of enteric neurons, 
independent of RET/GFR $\alpha 1 /$ GDNF signaling and dependent on extrinsic innervation. Additionally, tamoxifen-induced tracing initiated at E12.5 in Sox10-CreER ${ }^{T 2}$; Rosa26 $6^{\text {YFP }}$ mice resulted in tracing of 30-40\% of enteric neurons when inspected at postnatal stages [17]. Taking in consideration that there is no migratory crest after E10.5, SCPs were hypothesized to be a probable additional source of enteric neurons, pre- and postnataly, in addition to the early waves derived from the vagal and sacral neural crest [17].

To analyse if enteric neurons in $\mathrm{Ret}^{-/-}$and $\mathrm{Gfral}^{-/-}$mice were indeed derived from SCPs, Uesaka and colleagues utilised the following strategy: Dhh-Cre mice ( $D h h$ is expressed specifically in SCPs) were crossed with $G f r \alpha I^{-/-}$mice caring the $\operatorname{Ret}^{f l-C F P /+}$ reporter allele (upon the recombination, one allele of Ret is inactivated, and CFP is activated to label the cells [94]). Elimination of Gfral did not limit SCPs from generating submucosal neurons, thus, strongly suggesting their role in generating enteric neurons in the absence of enteric NCC (ENCC) [15].

The analysis of distribution of traced cells in Dhh-Cre;Ret ${ }^{f-C F P /+}$ 1-month-old mice showed that SCP contribution to the neurons of small and large intestine differed substantially. Only $5 \%$ of neurons in small intestine submucosal ganglia occurred to be SCP-derived. Similarly, SCP-derived neurons were barely found in the myenteric plexus of the small intestine [15].

In the large intestine, around $20 \%$ of neurons are SCPderived, populating both myenteric and submucosal layers. Most SCP-derived neurons express key enteric neurotransmitters Calb2 and nNos and form synapses with immediate neural crest-derived neurons, indicating the efficient integration in the intrinsic neural circuits [15]. Furthermore, lineage tracing in Sox 10-CreER ${ }^{T 2}$; Rosa $26^{\text {Confetti }}$ reporter mice induced at E12.5 and analysed in adult stages revealed SCPderived clones being composed of only neuronal or only glial cells, or neuro-glial mixtures. The identified clones occupied a compact space indicating a limited potential for migration of the progenitor cells within myenteric and submucosal layers. The clonal organisation of the ENS has implications in sister cell-neurons responding to external stimuli in a synchronized manner in comparison with nonrelated cells [95].

Additionally, the inspection of rostral levels of the digestive system revealed a significant proportion of the esophageal neurons being SCP-derived [16]. SCPs reach the developing esophagus via the incoming vagus nerve, which is found covered by $\mathrm{SOX} 10^{+} / \mathrm{PHOX}_{2} \mathrm{~B}^{+} / \mathrm{PLP}^{+} / \mathrm{CDH} 19^{+}$ cells at E11.5. This suggestion has been validated by a set of genetic ablation and lineage tracing experiments. For instance, the partial ablation of the vagus nerve (achieved by the expression of a toxic version of ASIC2A under the control of Phox 2 a promoter) led to a $36 \%$ reduction of SOX $10^{+}$ cells and $\mathrm{PHOX} 2 \mathrm{~B}^{+}$neuronal precursors in the esophagus.
Experimental disruption of the ERBB3-NRG1 signalling inhibited SCP migration along the vagus nerve, which resulted in esophageal ganglia being depleted of neurons by half [16]. Therefore, during embryogenesis, the esophageal ENS is derived from vagal NCCs starting to invade the wall of esophagus at E9.5 and being complemented by SCPs from the vagus nerve from E10.5 and onwards (Fig. 5b).

Altogether, these findings show that initial waves of enteric neurogenesis originate from the vagal and sacral neural crest and are being doped at later stages by a wave of SCP-derived neurogenesis. The enteric neurons, which are generated at different stages and from different immediate origins, integrate into fully functional units. Interestingly, SCP-driven enteric neurogenesis is evident in a postnatal ENS injury model, where $\mathrm{SOX} 10^{+}$cells give rise to the enteric neurons in adult mice during regeneration [17]. The most recent finding indicates that in post-embryonic zebra fish SCPs associated with the extrinsic gut innervation but not the enteric resident precursor cells are responcible for de novo neurogenesis [96].

\section{Clinical implications of SCP multipotency}

SCPs are multipotent nerve-associated cells, giving rise to neuronal or neuroendocrine subpopulations of the peripheral nervous system. Parasympathetic, sympathoadrenal and enteric domains demonstrate various degree of SCPderived neurons. Abnormalities of SCPs migration and differentiation towards these neuronal cell types might result in specific congenital diseases associated with SCP-derived neurogenesis.

The sympathoadrenal system including chromaffin and sympathetic cells as well as oxygen-sensing cells of carotid body is a well-known source of several malignancies. For instance, sympatho-adrenal cells might be the source of an early childhood cancer neuroblastoma [97] and an adult cancer pheochromocytoma [98]. The extra-medullary sympatho-adrenal cells of the organ of Zuckerkandl disintegrate in healthy individuals by the age of 3 years. However, failure in this process might cause tumors during adulthood [99, 100]. Additionally, oxygen-sensing glomus cells give rise to paraganglioma in adults [101, 102].

Neuroblastoma is the solid extra-cranial tumor associated with genetic defects in transcriptional factors MYCN, ALK [103], and PHOX2B [104, 105], which play important role in sympatho-adrenal lineage development (reviewed in [106]). There are several ways to classify neuroblastoma tumors. In 2009, International Neuroblastoma Risk Group (INRG) Task Force has proposed a system, which included age, histologic category, grade of tumor differentiation, the status of the MYCN oncogene, chromosome 11q status, and 
DNA ploidy as characteristics of the tumors. This system is currently used in clinical practice to diagnose and plan the future therapy [107]. A complementary study of gene expression profiles identified by microarrays further characterized the types of tumors and classified additional tumor types associated with poor prognosis [108]. Based on this recent classification, low risk tumors belong to the type 1 and are characterized by triploid DNA content, numeric alterations, and high expression of TRKA [109, 110]. Intermediate risk tumors do not have MYCN alterations, but demonstrate typical for neuroblastoma chromosomal aberrations: deletion of $11 \mathrm{q}$ and gain of $17 \mathrm{q}$, which help to classify the tumors as type $2 \mathrm{~A}$. Type $2 \mathrm{~B}$ is a high-risk neuroblastoma and presents many similarities to type $2 \mathrm{~A}$ with a key difference of carrying Mycn gene amplification.

One of the most enigmatic features of neuroblastoma is the phenomenon of spontaneous regression (referred to as type 4 S), which can happen in about $10 \%$ of detected cases [111]. Moreover, there is a specific type of neuroblastoma with metastases in skin, liver and bone marrow, which also falls in the group of self-regressing tumors. Such spontaneous regression sometimes leads to ganglioneuroma-a benign type of tumor (reviewed in [112].

Several studies pointed to the fact that multipotency is retained in some neuroblastoma tumors, which hypothetically might be explained by the SCP-related developmental origin of chromaffin cells and some sympathoblasts. Neuroblastoma tumors are mixed tumors, composed of an adrenergic component identified by the expression of Phox $2 b$, Hand2, Gata3 and a mesenchymal component (also referred to as a NCC-like component) identified by the expression of Prrxl, Vim, Snai2, Fosl1/2, Jun and others [113, 114]. Although the genetic abnormalities observed in the cells composing neuroblastoma tumors are largely uniform, the super-enhancer-associated transcription factor networks and corresponding transcriptional profiles are different for adrenergic-like and mesenchymal populations. Furthermore, there is evidence of adrenergic-to-mesenchymal and mesenchymal-to-adrenergic transitions, which may result in unwanted relapses and therapy tolerance observed in neuroblastoma [113-115]. Finally, even though neuroblastoma is hypothesized to originate from the migratory and sympatho-adrenal neural crest, there might be clinical cases, where abnormal Schwann cell lineage causes specific neuroblastoma and pheochromocytoma subtypes.

Another relevant tumorigenic disease is neurofibromatosis type 1 (reviewed in [116]). The mutation in $N f 1$ gene causes cells belonging to the Schwann cell lineage to be susceptible to benign tumor formation $[117,118]$; however, to form neurofibromas, the $\mathrm{NFl}$ deficient microenvironment is also necessary [119]. In Dhh-Cre; $\mathrm{Nf}^{\ell l f l}$ and $\mathrm{Mpz}-\mathrm{Cre} ; \mathrm{NfI}$ $f / f l$ mice with $N f l$ gene was removed from the Schwann cell lineage, the development of plexiform neurofibromas, dermal neurofibromas, and pigmentation was observed [120, 121]. Therefore, one of the possible cells of origin of neurofibromatosis type 1 is SCP in their transition to immature SCs. Within neurofibromas, different cell types including NF1-deficient Schwann cell-like cells, fibroblasts, perineurial-like cells, neural cell elements (mainly processes) [122] and recruited mast cells [123] co-exist and grow. There is a need to better understand what triggers differentiation of SCPs into these abnormal cell types to prevent the further development of neurofibromatosis.

Finally, the failure of precursor cells to reach and colonize the gut is the reason for Hirschsprung's disease characterized by the lack of innervation in the distal portion of the bowel. Consistently, in case of Hirschsprung's disease, the external nerves innervating the gut are abnormally thick with excessive NGF levels and accumulation of $\mathrm{p}^{+} / \mathrm{S}^{+} 100^{+}$glial cells $[124,125]$ resembling SCPs. Currently, the surgical removal of aganglionic gut is a widely used treatment for the disorder. However, there are challenges in the surgery if a substantial portion of gut is de-innervated. Therefore, the need for an alternative therapy persists. In principle, SCPs and SCs can be harvested from the healthy portion of the gut, expanded in a neurosphere culture and subsequently transplanted into the aganglionic portion of the gut for regenerating local ENS [125, 126]. Moreover, the presence of SCPs associated with extrinsic innervation in the gut of Hirschsprung's disease patients raises the possibility [127] of a therapy based on the direct induction of neuronal differentiation of these precursor cells within the gut walls [125].

\section{Concluding remarks}

The last decade of research significantly expanded our insights into the multipotency and key roles that SCPs play in the body. Starting from a non-mainstream finding of SCP-derived melanocytes in 2009 [10], the field underwent inflation and generated the knowledge of SCPs contributing to numerous cell types previously known as descendants of NCCs. Today, SCPs are rather seen as a continuation of NCCs that occupies the nerves and utilizes the innervation as a navigating route. Because spatial and temporal heterogeneity of SCPs still remains elusive, further innovations in single-cell epigenetic, genomic and spatial transcriptomic technologies will largely advance our understanding of regional differences in SCPs including their local differentiation potential.

SCPs might be a perfect adaptation to accommodate for a fast embryonic growth and arising deficits of free migration (the concept is proposed in [25]). In line with this, it is tempting to suggest that a small pool of undifferentiated SCPs remains associated with nerves and can serve 
as a stem cell population recruited upon the need of tissue regeneration or as in the case of the carotid body additional growth as an adjustment to chronic hypoxia. SCs are known to de-differentiate in case of nerve injury, re-enter the cell cycle and assist in the axon regeneration (for review [128]). Therefore, SCs from patient-derived skin biopsies could be reprogrammed and used in regenerative strategies via activation of SCP-like multipotency.

Acknowledgements Open access funding provided by Karolinska Institutet. The authors were supported by European Research Council Consolidator grant STEMMING-FROM-NERVE, European Research Council Synergy grant KILL-OR-DIFFERENTIATE, Swedish Research Council, Cancer Fonden, Bertil Hallsten Research Foundation, Paradifference Foundation, Knut and Alice Wallenberg Foundation. MEK was supported by the Novo Nordisk Foundation (Postdoc fellowship in Endocrinology and Metabolism at International Elite Environments, NNF17OC0026874) and Stiftelsen Riksbankens Jubileumsfond (Erik Rönnbergs fond stipend).

Open Access This article is licensed under a Creative Commons Attribution 4.0 International License, which permits use, sharing, adaptation, distribution and reproduction in any medium or format, as long as you give appropriate credit to the original author(s) and the source, provide a link to the Creative Commons licence, and indicate if changes were made. The images or other third party material in this article are included in the article's Creative Commons licence, unless indicated otherwise in a credit line to the material. If material is not included in the article's Creative Commons licence and your intended use is not permitted by statutory regulation or exceeds the permitted use, you will need to obtain permission directly from the copyright holder. To view a copy of this licence, visit http://creativecommons.org/licenses/by/4.0/.

\section{References}

1. Jessen KR, Mirsky R (2005) The origin and development of glial cells in peripheral nerves. Nat Rev Neurosci 6(9):671-682. https ://doi.org/10.1038/nrn1746

2. Jessen KR, Mirsky R (2019) Schwann cell precursors; multipotent glial cells in embryonic nerves. Front Mol Neurosci. https:// doi.org/10.3389/fnmol.2019.00069

3. Garratt AN, Britsch S, Birchmeier C (2000) Neuregulin, a factor with many functions in the life of a schwann cell. BioEssays 22(11):987-996. https://doi.org/10.1002/1521-1878(20001 1)22:11

4. Britsch S, Li L, Kirchhoff S, Theuring F, Brinkmann V, Birchmeier C, Riethmacher D (1998) The ErbB2 and ErbB3 receptors and their ligand, neuregulin-1, are essential for development of the sympathetic nervous system. Genes Dev 12(12):1825-1836. https://doi.org/10.1101/gad.12.12.1825

5. Honjo Y, Kniss J, Eisen JS (2008) Neuregulin-mediated ErbB3 signaling is required for formation of zebrafish dorsal root ganglion neurons. Development 135(15):2615-2625. https://doi. org/10.1242/dev.022178

6. Riethmacher D, Sonnenberg-Riethmacher E, Brinkmann V, Yamaai T, Lewin GR, Birchmeier C (1997) Severe neuropathies in mice with targeted mutations in the ErbB3 receptor. Nature 389(6652):725-730. https://doi.org/10.1038/39593

7. Taveggia C, Feltri ML, Wrabetz L (2010) Signals to promote myelin formation and repair. Nat Rev Neurol 6(5):276-287. https ://doi.org/10.1038/nrneurol.2010.37
8. Taveggia C, Zanazzi G, Petrylak A, Yano H, Rosenbluth J, Einheber S, Xu X, Esper RM, Loeb JA, Shrager P, Chao MV, Falls DL, Role L, Salzer JL (2005) Neuregulin-1 type III determines the ensheathment fate of axons. Neuron 47(5):681-694. https:// doi.org/10.1016/j.neuron.2005.08.017

9. Petersen J, Adameyko I (2017) Nerve-associated neural crest: peripheral glial cells generate multiple fates in the body. Curr Opin Genet Dev 45:10-14. https://doi.org/10.1016/j. gde.2017.02.006

10. Adameyko I, Lallemend F, Aquino JB, Pereira JA, Topilko P, Muller T, Fritz N, Beljajeva A, Mochii M, Liste I, Usoskin D, Suter U, Birchmeier C, Ernfors P (2009) Schwann cell precursors from nerve innervation are a cellular origin of melanocytes in skin. Cell 139(2):366-379. https://doi.org/10.1016/j. cell.2009.07.049

11. Singh AP, Dinwiddie A, Mahalwar P, Schach U, Linker C, Irion U, Nüsslein-Volhard C (2016) Pigment cell progenitors in zebrafish remain multipotent through metamorphosis. Dev Cell 38(3):316-330. https://doi.org/10.1016/j.devcel.2016.06.020

12. Whitlock KE, Smith KM, Kim H, Harden MV (2005) A role for Foxd3 and Sox 10 in the differentiation of gonadotropin-releasing hormone $(\mathrm{GnRH})$ cells in the zebrafish Danio rerio. Development 132(24):5491-5502. https://doi.org/10.1242/dev.02158

13. Dyachuk V, Furlan A, Khatibi Shahidi M, Giovenco M, Kaukua N, Konstantinidou C, Pachnis V, Memic F, Marklund U, Müller T, Birchmeier C, Fried K, Ernfors P, Adameyko I (2014) Parasympathetic neurons originate from nerve-associated peripheral glial progenitors. Science 345(6192):82-87. https://doi. org/10.1126/science.1253281

14. Espinosa-Medina I, Outin E, Picard CA, Chettouh Z, Dymecki S, Consalez GG, Coppola E, Brunet J-F (2014) Parasympathetic ganglia derive from Schwann cell precursors. Science 345(6192):87-90. https://doi.org/10.1126/science.1253286

15. Uesaka T, Nagashimada M, Enomoto H (2015) Neuronal differentiation in schwann cell lineage underlies postnatal neurogenesis in the enteric nervous system. J Neurosci 35(27):98799888. https://doi.org/10.1523/jneurosci.1239-15.2015

16. Espinosa-Medina I, Jevans B, Boismoreau F, Chettouh Z, Enomoto H, Müller T, Birchmeier C, Burns AJ, Brunet J-F (2017) Dual origin of enteric neurons in vagal Schwann cell precursors and the sympathetic neural crest. Proc Natl Acad Sci 114(45):11980-11985. https://doi.org/10.1073/pnas.17103 08114

17. Laranjeira C, Sandgren K, Kessaris N, Richardson W, Potocnik A, Vanden Berghe P, Pachnis V (2011) Glial cells in the mouse enteric nervous system can undergo neurogenesis in response to injury. J Clin Invest 121(9):3412-3424. https://doi. org/10.1172/JCI58200

18. Furlan A, Dyachuk V, Kastriti ME, Calvo-Enrique L, Abdo H, Hadjab S, Chontorotzea T, Akkuratova N, Usoskin D, Kamenev D, Petersen J, Sunadome K, Memic F, Marklund U, Fried K, Topilko P, Lallemend F, Kharchenko PV, Ernfors P, Adameyko I (2017) Multipotent peripheral glial cells generate neuroendocrine cells of the adrenal medulla. Science. https:// doi.org/10.1126/science.aal3753

19. Kastriti ME, Kameneva P, Kamenev D, Dyachuk V, Furlan A, Hampl M, Memic F, Marklund U, Lallemend F, Hadjab S, Calvo-Enrique L, Ernfors P, Fried K, Adameyko I (2019) Schwann cell precursors generate the majority of chromaffin cells in zuckerkandl organ and some sympathetic neurons in paraganglia. Front Mol Neurosci. https://doi.org/10.3389/ fnmol.2019.00006

20. Hockman D, Adameyko I, Kaucka M, Barraud P, Otani T, Hunt A, Hartwig AC, Sock E, Waithe D, Franck MCM, Ernfors P, Ehinger S, Howard MJ, Brown N, Reese J, Baker CVH (2018) Striking parallels between carotid body glomus cell and adrenal 
chromaffin cell development. Dev Biol 444(Suppl 1):S308-S324. https://doi.org/10.1016/j.ydbio.2018.05.016

21. Joseph NM, Mukouyama YS, Mosher JT, Jaegle M, Crone SA, Dormand EL, Lee KF, Meijer D, Anderson DJ, Morrison SJ (2004) Neural crest stem cells undergo multilineage differentiation in developing peripheral nerves to generate endoneurial fibroblasts in addition to Schwann cells. Development 131(22):5599-5612. https://doi.org/10.1242/dev.01429

22. Isern J, García-García A, Martín AM, Arranz L, Martín-Pérez D, Torroja C, Sánchez-Cabo F, Méndez-Ferrer S (2014) The neural crest is a source of mesenchymal stem cells with specialized hematopoietic stem cell niche function. eLife 3:e03696. https:// doi.org/10.7554/elife.03696

23. Kaukua N, Shahidi MK, Konstantinidou C, Dyachuk V, Kaucka M, Furlan A, An Z, Wang L, Hultman I, Ahrlund-Richter L, Blom H, Brismar H, Lopes NA, Pachnis V, Suter U, Clevers H, Thesleff I, Sharpe P, Ernfors P, Fried K, Adameyko I (2014) Glial origin of mesenchymal stem cells in a tooth model system. Nature 513(7519):551-554. https://doi.org/10.1038/nature1353 6

24. Xie M, Kamenev D, Kaucka M, Kastriti ME, Zhou B, Artemov AV, Storer M, Fried K, Adameyko I, Dyachuk V, Chagin AS (2019) Schwann cell precursors contribute to skeletal formation during embryonic development in mice and zebrafish. Proc Natl Acad Sci 116(30):15068-15073. https://doi.org/10.1073/ pnas. 1900038116

25. La Manno G, Soldatov R, Zeisel A, Braun E, Hochgerner H, Petukhov V, Lidschreiber K, Kastriti ME, Lönnerberg P, Furlan A, Fan J, Borm LE, Liu Z, van Bruggen D, Guo J, He X, Barker R, Sundström E, Castelo-Branco G, Cramer P, Adameyko I, Linnarsson S, Kharchenko PV (2018) RNA velocity of single cells. Nature 560(7719):494-498. https://doi.org/10.1038/s4158 6-018-0414-6

26. Green SA, Uy BR, Bronner ME (2017) Ancient evolutionary origin of vertebrate enteric neurons from trunk-derived neural crest. Nature 544(7648):88-91. https://doi.org/10.1038/nature21679

27. Soldatov R, Kaucka M, Kastriti ME, Petersen J, Chontorotzea T, Englmaier L, Akkuratova N, Yang Y, Haring M, Dyachuk V, Bock C, Farlik M, Piacentino ML, Boismoreau F, Hilscher MM, Yokota C, Qian X, Nilsson M, Bronner ME, Croci L, Hsiao WY, Guertin DA, Brunet JF, Consalez GG, Ernfors P, Fried K, Kharchenko PV, Adameyko I (2019) Spatiotemporal structure of cell fate decisions in murine neural crest. Science. https://doi. org/10.1126/science.aas 9536

28. Wakamatsu Y, Maynard TM, Weston JA (2000) Fate determination of neural crest cells by NOTCH-mediated lateral inhibition and asymmetrical cell division during gangliogenesis. Development 127:2811-2821

29. Morrison SJ, Perez SE, Qiao Z, Verdi JM, Hicks C, Weinmaster C, Anderson DJ (2000) Transient notch activation initiates an an irreversible switch from neurogenesis to gliogenesis by neural crest stem cells. Cell 101:499-510

30. Wiszniak S, Schwarz Q (2019) Notch signalling defines dorsal root ganglia neuroglial fate choice during early neural crest cell migration. BMC Neurosci 20(1):21. https://doi.org/10.1186/ s12868-019-0501-0

31. Adameyko I, Lallemend F, Furlan A, Zinin N, Aranda S, Kitambi SS, Blanchart A, Favaro R, Nicolis S, Lubke M, Muller T, Birchmeier C, Suter U, Zaitoun I, Takahashi Y, Ernfors P (2012) Sox2 and Mitf cross-regulatory interactions consolidate progenitor and melanocyte lineages in the cranial neural crest. Development 139(2):397-410. https://doi.org/10.1242/dev.065581

32. Paratore C, Goerich DE, Suter U, Wegner M, Sommer L (2001) Survival and glial fate acquisition of neural crest cells are regulated by an interplay between the transcription factor Sox 10 and extrinsic combinatorial signaling. Development 128(20):3949-3961

33. Jacob C, Lotscher P, Engler S, Baggiolini A, Varum Tavares S, Brugger V, John N, Buchmann-Moller S, Snider PL, Conway SJ, Yamaguchi T, Matthias P, Sommer L, Mantei N, Suter U (2014) HDAC1 and HDAC2 control the specification of neural crest cells into peripheral glia. J Neurosci 34(17):6112-6122. https:// doi.org/10.1523/jneurosci.5212-13.2014

34. Jacob C, Christen CN, Pereira JA, Somandin C, Baggiolini A, Lotscher P, Ozcelik M, Tricaud N, Meijer D, Yamaguchi T, Matthias P, Suter U (2011) HDAC1 and HDAC2 control the transcriptional program of myelination and the survival of Schwann cells. Nat Neurosci 14(4):429-436. https://doi.org/10.1038/ nn. 2762

35. Chen Y, Wang H, Yoon SO, Xu X, Hottiger MO, Svaren J, Nave KA, Kim HA, Olson EN, Lu QR (2011) HDAC-mediated deacetylation of NF-kappaB is critical for Schwann cell myelination. Nat Neurosci 14(4):437-441. https://doi.org/10.1038/nn.2780

36. Rao A, LaBonne C (2018) Histone deacetylase activity has an essential role in establishing and maintaining the vertebrate neural crest. Development. https://doi.org/10.1242/dev.163386

37. Jacob C (2015) Transcriptional control of neural crest specification into peripheral glia. Glia 63(11):1883-1896. https://doi. org/10.1002/glia.22816

38. Wahlbuhl M, Reiprich S, Vogl MR, Bösl MR, Wegner M (2011) Transcription factor Sox 10 orchestrates activity of a neural crestspecific enhancer in the vicinity of its gene. Nucleic Acids Res 40(1):88-101. https://doi.org/10.1093/nar/gkr734

39. Nitzan E, Pfaltzgraff ER, Labosky PA, Kalcheim C (2013) Neural crest and Schwann cell progenitor-derived melanocytes are two spatially segregated populations similarly regulated by Foxd3. Proc Natl Acad Sci U S A 110(31):12709-12714. https://doi. org/10.1073/pnas.1306287110

40. Schotzinger R, Yin X, Landis S (1994) Target determination of neurotransmitter phenotype in sympathetic neurons. J Neurobiol 25(6):620-639. https://doi.org/10.1002/neu.480250605

41. Francis NJ, Landis SC (1999) Cellular and molecular determinants of sympathetic neuron development. Annu Rev Neurosci 22:541-566. https://doi.org/10.1146/annurev.neuro.22.1.541

42. Furlan A, La Manno G, Lubke M, Haring M, Abdo H, Hochgerner H, Kupari J, Usoskin D, Airaksinen MS, Oliver G, Linnarsson S, Ernfors P (2016) Visceral motor neuron diversity delineates a cellular basis for nipple- and pilo-erection muscle control. Nat Neurosci 19(10):1331-1340. https://doi. org/10.1038/nn.4376

43. Akasu T, Nishimura T (1995) Synaptic transmission and function of parasympathetic ganglia. Prog Neurobiol 45(5):459-522. https ://doi.org/10.1016/0301-0082(95)98602-2

44. Dyavanapalli J, Dergacheva O, Wang X, Mendelowitz D (2016) Parasympathetic vagal control of cardiac function. Curr Hypertens Rep 18(3):22. https://doi.org/10.1007/s11906-016-0630-0

45. Narayanan $\mathrm{CH}$, Narayanan Y (1978) On the origin of the ciliary ganglion in birds studied by the method of interspecific transplantation of embryonic brain regions between quail and chick. Development 47(1):137-148

46. Lee VM, Sechrist JW, Luetolf S, Bronner-Fraser M (2003) Both neural crest and placode contribute to the ciliary ganglion and oculomotor nerve. Dev Biol 263(2):176-190. https://doi. org/10.1016/j.ydbio.2003.07.004

47. Espinosa-Medina I, Saha O, Boismoreau F, Brunet JF (2018) The "sacral parasympathetic": ontogeny and anatomy of a myth. Clin Auton Res 28(1):13-21. https://doi.org/10.1007/s1028 6-017-0478-7 
48. Horn JP (2018) The sacral autonomic outflow is parasympathetic: langley got it right. Clin Auton Res 28(2):181-185. https://doi. org/10.1007/s10286-018-0510-6

49. Maynard RL, Downes N (2019) Chapter 21 - Peripheral Nervous System. In: Maynard RL, Downes N (eds) Anatomy and Histology of the Laboratory Rat in Toxicology and Biomedical Research. Academic Press, pp 261-281. https://doi.org/10.1016/ b978-0-12-811837-5.00021-6

50. Espinosa-Medina I, Saha O, Boismoreau F, Chettouh Z, Rossi F, Richardson WD, Brunet JF (2016) The sacral autonomic outflow is sympathetic. Science 354(6314):893-897. https://doi. org/10.1126/science.aah5454

51. Neuhuber W, Mclachlan E, Jänig W (2017) The sacral autonomic outflow is spinal, but not "sympathetic". Anatom Record 300(8):1369-1370

52. Bornstein SR, Ehrhart-Bornstein M, Androutsellis-Theotokis A, Eisenhofer G, Vukicevic V, Licinio J, Wong ML, Calissano P, Nistico G, Preziosi P, Levi-Montalcini R (2012) Chromaffin cells: the peripheral brain. Mol Psychiatry 17(4):354-358. https ://doi.org/10.1038/mp.2011.176

53. Eiden LE, Jiang SZ (2018) What's New in Endocrinology: The Chromaffin Cell. Front Endocrinol. https://doi.org/10.3389/fendo 2018.00711

54. Seidler FJ, Slotkin TA (1985) Adrenomedullary function in the neonatal rat: responses to acute hypoxia. J Physiol 358:1-16. https://doi.org/10.1113/jphysiol.1985.sp015536

55. Levitsky KL, Lopez-Barneo J (2009) Developmental change of T-type $\mathrm{Ca} 2+$ channel expression and its role in rat chromaffin cell responsiveness to acute hypoxia. J Physiol 587(Pt 9):19171929. https://doi.org/10.1113/jphysiol.2009.168989

56. Le Douarin N, Teillet MA (1971) Localization, by the method of interspecific grafts of the neural area from which adrenal cells arise in the bird embryo. Comptes rendus hebdomadaires des seances de l'Academie des sciences Serie D: Sciences naturelles 272(3):481-484

57. Teillet MA, Le Douarin N (1974) Determination of the level of the origin of the adrenal medulla cells in the neural axis using heterospecific grafts of quail neural rudiments on chick embryos. Archives d'anatomie microscopique et de morphologie experimentale 63(1):51-62

58. Saito D, Takahashi Y (2015) Sympatho-adrenal morphogenesis regulated by the dorsal aorta. Mech Dev 138:2-7. https://doi. org/10.1016/j.mod.2015.07.011

59. Moriguchi T, Lim K-C, Engel JD (2007) Transcription factor networks specify sympathetic and adrenal chromaffin cell differentiation. Funct Dev Embryol 1(2):130-135

60. Aloe L, Levi-Montalcini R (1979) Nerve growth factor-induced transformation of immature chromaffin cells in vivo into sympathetic neurons: effect of antiserum to nerve growth factor. J Proc Natl Acad Sci U S A 76(3):1246-1250. https://doi.org/10.1073/ pnas.76.3.1246

61. Anderson DJ, Axel R (1986) A bipotential neuroendocrine precursor whose choice of cell fate is determined by NGF and glucocorticoids. Cell 47(6):1079-1090. https://doi.org/10.1016/00928674(86)90823-8

62. Gut P, Huber K, Lohr J, Brühl B, Oberle S, Treier M, Ernsberger U, Kalcheim C, Unsicker K (2005) Lack of an adrenal cortex in Sf1 mutant mice is compatible with the generation and differentiation of chromaffin cells. Develpoment 132(20):4611-4619. https://doi.org/10.1242/dev.02052

63. Finotto S, Krieglstein K, Schober A, Deimling F, Lindner K, Bruhl B, Beier K, Metz J, Garcia-Arraras JE, Roig-Lopez JL, Monaghan P, Schmid W, Cole TJ, Kellendonk C, Tronche F, Schutz G, Unsicker K (1999) Analysis of mice carrying targeted mutations of the glucocorticoid receptor gene argues against an essential role of glucocorticoid signalling for generating adrenal chromaffin cells. Development 126(13):2935-2944

64. Ernsberger U, Esposito L, Partimo S, Huber K, Franke A, Bixby JL, Kalcheim C, Unsicker K (2005) Expression of neuronal markers suggests heterogeneity of chick sympathoadrenal cells prior to invasion of the adrenal anlagen. Cell Tissue Res 319(1):1-13. https://doi.org/10.1007/s00441-004-0996-1

65. Lumb R, Tata M, Xu X, Joyce A, Marchant C, Harvey N, Ruhrberg C, Schwarz Q (2018) Neuropilins guide preganglionic sympathetic axons and chromaffin cell precursors to establish the adrenal medulla. Development. https://doi.org/10.1242/ dev. 162552

66. Nurse CA, Piskuric NA (2013) Signal processing at mammalian carotid body chemoreceptors. Semin Cell Dev Biol 24(1):22-30. https://doi.org/10.1016/j.semcdb.2012.09.006

67. Nurse CA (2014) Synaptic and paracrine mechanisms at carotid body arterial chemoreceptors. J Physiol 592(16):3419-3426. https://doi.org/10.1113/jphysiol.2013.269829

68. Le Douarin N, Le Lièvre C (1972) Fontaine JJCAS. Recherches experimentales sur l'origine embryologique du corps carotidien chez les oiseaux. 275:583-586

69. Pardal R, Ortega-Sáenz P, Durán R, López-Barneo JJC (2007) Glia-like stem cells sustain physiologic neurogenesis in the adult mammalian carotid body. Cell 131(2):364-377

70. Schemann M (2005) Control of gastrointestinal motility by the "gut brain"-the enteric nervous system. J Pediatr Gastroenterol Nutr 41(Suppl 1):S4-S6. https://doi.org/10.1097/01.scs.00001 80285.51365 .55

71. Hyland NP, Cryan JF (2016) Microbe-host interactions: influence of the gut microbiota on the enteric nervous system. Dev Biol 417(2):182-187. https://doi.org/10.1016/j.ydbio.2016.06.027

72. De Vadder F, Grasset E, Mannerås Holm L, Karsenty G, Macpherson AJ, Olofsson LE, Bäckhed F (2018) Gut microbiota regulates maturation of the adult enteric nervous system via enteric serotonin networks. J Proc Natl Acad Sci U S A 115(25):6458-6463. https://doi.org/10.1073/pnas.1720017115

73. Zeisel A, Hochgerner H, Lönnerberg P, Johnsson A, Memic F, van der Zwan J, Häring M, Braun E, Borm LE, La Manno G, Codeluppi S, Furlan A, Lee K, Skene N, Harris KD, Hjerling-Leffler J, Arenas E, Ernfors P, Marklund U, Linnarsson $S$ (2018) Molecular architecture of the mouse nervous system. Cell 174(4):999-1014.e1022. https://doi.org/10.1016/j. cell.2018.06.021

74. Hockley JRF, Taylor TS, Callejo G, Wilbrey AL, Gutteridge A, Bach K, Winchester WJ, Bulmer DC, McMurray G, Smith ESJ (2019) Single-cell RNAseq reveals seven classes of colonic sensory neuron. Nature 68(4):633-644. https://doi.org/10.1136/gutjn 1-2017-315631

75. Lau ST, Li Z, Pui-Ling Lai F, Nga-Chu Lui K, Li P, Munera JO, Pan G, Mahe MM, Hui CC, Wells JM, Ngan ES (2019) Activation of hedgehog signaling promotes development of mouse and human enteric neural crest cells, based on single-cell transcriptome analyses. Gastroenterology 157(6):1556-1571.e1555. https ://doi.org/10.1053/j.gastro.2019.08.019

76. Yntema CL, Hammond WS (1954) The origin of intrinsic ganglia of trunk viscera from vagal neural crest in the chick embryo. J Compar Neurol 101(2):515-541. https://doi.org/10.1002/ cne.901010212

77. Le Douarin NM, Teillet MA (1973) The migration of neural crest cells to the wall of the digestive tract in avian embryo. $\mathrm{J}$ Embryology Exp Morphol 30(1):31-48

78. Burns AJ, Le Douarin NM (2001) Enteric nervous system development: Analysis of the selective developmental potentialities of vagal and sacral neural crest cells using quail-chick chimeras. Anatom Rec 262(1):16-28. https://doi.org/10.1002/10970185(20010101)262:1\%3c16:Aid-ar1007\%3e3.0.Co;2-o 
79. Young HM, Bergner AJ, Anderson RB, Enomoto H, Milbrandt J, Newgreen DF, Whitington PM (2004) Dynamics of neural crestderived cell migration in the embryonic mouse gut. Dev Biol 270(2):455-473. https://doi.org/10.1016/j.ydbio.2004.03.015

80. Delalande JM, Barlow AJ, Thomas AJ, Wallace AS, Thapar N, Erickson CA, Burns AJ (2008) The receptor tyrosine kinase RET regulates hindgut colonization by sacral neural crest cells. Dev Biol 313(1):279-292. https://doi.org/10.1016/j.ydbio 2007.10.028

81. Kapur RP (2000) Colonization of the murine hindgut by sacral crest-derived neural precursors: experimental support for an evolutionarily conserved model. Dev Biol 227(1):146-155. https:// doi.org/10.1006/dbio.2000.9886

82. Nagy N, Goldstein AM (2017) Enteric nervous system development: a crest cell's journey from neural tube to colon. Semin Cell Dev Biol 66:94-106. https://doi.org/10.1016/j.semcd b.2017.01.006

83. Rothman TP, Gershon MD (1982) Phenotypic expression in the developing murine enteric nervous system. J Neurosci 2(3):381-393

84. Branchek TA, Gershon MD (1989) Time course of expression of neuropeptide Y, calcitonin gene-related peptide, and NADPH diaphorase activity in neurons of the developing murine bowel and the appearance of 5-hydroxytryptamine in mucosal enterochromaffin cells. J Comp Neurol 285(2):262-273. https://doi. org/10.1002/cne. 902850208

85. Takahashi M (2001) The GDNF/RET signaling pathway and human diseases. Cytokine Growth Factor Rev 12(4):361-373. https://doi.org/10.1016/S1359-6101(01)00012-0

86. Hao MM, Bergner AJ, Nguyen HTH, Dissanayake P, Burnett LE, Hopkins CD, Zeng K, Young HM, Stamp LA (2019) Role of JNK, MEK and adenylyl cyclase signalling in speed and directionality of enteric neural crest-derived cells. Dev Biol 455(2):362-368. https://doi.org/10.1016/j.ydbio.2019.07.007

87. Natarajan D, Marcos-Gutierrez C, Pachnis V, de Graaff EJD (2002) Requirement of signalling by receptor tyrosine kinase RET for the directed migration of enteric nervous system progenitor cells during mammalian embryogenesis. Development 129(22):5151-5160

88. Durbec PL, Larsson-Blomberg LB, Schuchardt A, Costantini F, Pachnis VJD (1996) Common origin and developmental dependence on c-ret of subsets of enteric and sympathetic neuroblasts. Development 122(1):349-358

89. Schuchardt A, D'Agati V, Larsson-Blomberg L, Costantini F, Pachnis VJN (1994) Defects in the kidney and enteric nervous system of mice lacking the tyrosine kinase receptor Ret. Nature 367(6461):380-383

90. Moore MW, Klein RD, Fariñas I, Sauer H, Armanini M, Phillips H, Reichardt LF, Ryan AM, Carver-Moore K, Rosenthal AJN (1996) Renal and neuronal abnormalities in mice lacking GDNF. Nature 382(6586):76-79

91. Pichel JG, Shen L, Sheng HZ, Granholm A-C, Drago J, Grinberg A, Lee EJ, Huang SP, Saarma M, Hoffer BJJN (1996) Defects in enteric innervation and kidney development in mice lacking GDNF. Nature 382(6586):73-76

92. Sánchez MP, Silos-Santiago I, Frisén J, He B, Lira SA, Barbacid MJN (1996) Renal agenesis and the absence of enteric neurons in mice lacking GDNF. Nature 382(6586):70-73

93. Cacalano G, Fariñas I, Wang LC, Hagler K, Forgie A, Moore M, Armanini M, Phillips H, Ryan AM, Reichardt LF, Hynes M (1998) GFR $\alpha 1$ is an essential receptor component for GDNF in the developing nervous system and kidney. Neuron 21(1):53-62

94. Uesaka T, Nagashimada M, Yonemura S, Enomoto H (2008) Diminished Ret expression compromises neuronal survival in the colon and causes intestinal aganglionosis in mice. J Clin Investig 118(5):1890-1898. https://doi.org/10.1172/JCI34425
95. Lasrado R, Boesmans W, Kleinjung J, Pin C, Bell D, Bhaw L, McCallum S, Zong H, Luo L, Clevers H, Vanden Berghe P, Pachnis V (2017) Lineage-dependent spatial and functional organization of the mammalian enteric nervous system. Science 356(6339):722-726. https://doi.org/10.1126/science.aam7511

96. El-Nachef WN, Bronner ME (2020) Development 147 (13): dev186619

97. Maris JM, Hogarty MD, Bagatell R, Cohn SL (2007) Neuroblastoma. Lancet 369(9579):2106-2120. https://doi.org/10.1016/ S0140-6736(07)60983-0

98. Turchini J, Cheung VKY, Tischler AS, De Krijger RR, Gill AJ (2018) Pathology and genetics of phaeochromocytoma and paraganglioma. Histopathology 72(1):97-105. https://doi. org/10.1111/his.13402

99. Gill T, Adler K, Schrader A, Desai K, Wermers J, Beteselassie N (2017) Extra-adrenal pheochromocytoma at the organ of Zuckerkandl: a case report and literature review. Radiol Case Rep 12(2):343-347. https://doi.org/10.1016/j.radcr.2016.12.009

100. Petri BJ, van Eijck CH, de Herder WW, Wagner A, de Krijger RR (2009) Phaeochromocytomas and sympathetic paragangliomas. Br J Surg 96(12):1381-1392. https://doi.org/10.1002/bjs.6821

101. Naik SM, Shenoy AM, Nanjundappa Halkud R, Chavan P, Sidappa K, Amritham U, Gupta S (2013) Paragangliomas of the carotid body: current management protocols and review of literature. Indian J Surg Oncol 4(3):305-312. https://doi.org/10.1007/ s13193-013-0249-4

102. Davidovic LB, Djukic VB, Vasic DM, Sindjelic RP, Duvnjak SN (2005) Diagnosis and treatment of carotid body paraganglioma: 21 years of experience at a clinical center of Serbia. World J Surg Oncol 3(1):10. https://doi.org/10.1186/1477-7819-3-10

103. Janoueix-Lerosey I, Lopez-Delisle L, Delattre O, Rohrer H (2018) The ALK receptor in sympathetic neuron development and neuroblastoma. Cell Tissue Res 372(2):325-337. https:// doi.org/10.1007/s00441-017-2784-8

104. Trochet D, Bourdeaut F, Janoueix-Lerosey I, Deville A, de Pontual L, Schleiermacher G, Coze C, Philip N, Frébourg T, Munnich A, Lyonnet S, Delattre O, Amiel J (2004) Germline Mutations of the Paired-Like Homeobox 2B (PHOX2B) Gene in Neuroblastoma. Am J Hum Genet 74(4):761-764. https:// doi.org/10.1086/383253

105. Mosse YP, Laudenslager M, Khazi D, Carlisle AJ, Winter CL, Rappaport E, Maris JM (2004) Germline PHOX2B Mutation in Hereditary Neuroblastoma. Am J Hum Genet 75(4):727-730. https://doi.org/10.1086/424530

106. Huber K, Janoueix-Lerosey I, Kummer W, Rohrer H, Tischler AS (2018) The sympathetic nervous system: malignancy, disease, and novel functions. Cell Tissue Res 372(2):163-170. https://doi.org/10.1007/s00441-018-2831-0

107. Cohn SL, Pearson AD, London WB, Monclair T, Ambros PF, Brodeur GM, Faldum A, Hero B, Iehara T, Machin D, Mosseri V (2009) The International Neuroblastoma Risk Group (INRG) classification system: an INRG task force report. J Clin Oncol 27(2):289

108. Abel F, Dalevi D, Nethander M, Jörnsten R, De Preter K, Vermeulen J, Stallings R, Kogner P, Maris J, Nilsson S (2011) A 6-gene signature identifies four molecular subgroups of neuroblastoma. Cancer Cell Int 11(1):9. https://doi.org/10.1186/1475-2867-11-9

109. Kogner P, Barbany G, Bjork O, Castello MA, Donfrancesco A, Falkmer UG, Hedborg F, Kouvidou H, Persson H, Raschella G et al (1994) Trk mRNA and low affinity nerve growth factor receptor mRNA expression and triploid DNA content in favorable neuroblastoma tumors. Prog Clin Biol Res 385:137-145

110. Kogner P, Barbany G, Dominici C, Castello MA, Raschella G, Persson H (1993) Coexpression of messenger RNA for TRK protooncogene and low affinity nerve growth factor 
receptor in neuroblastoma with favorable prognosis. Cancer Res 53(9):2044-2050

111. D'Angio G, Evans A, Koop CE (1971) Special pattern of widespread neuroblastoma with a favourable prognosis. Lancet 297(7708):1046-1049. https://doi.org/10.1016/S0140 $-6736(71) 91606-0$

112. Brodeur GM (2018) Spontaneous regression of neuroblastoma. Cell Tissue Res 372(2):277-286. https://doi.org/10.1007/s0044 1-017-2761-2

113. Boeva V, Louis-Brennetot C, Peltier A, Durand S, Pierre-Eugene C, Raynal V, Etchevers HC, Thomas S, Lermine A, DaudigeosDubus E, Geoerger B, Orth MF, Grunewald TGP, Diaz E, Ducos B, Surdez D, Carcaboso AM, Medvedeva I, Deller T, Combaret V, Lapouble E, Pierron G, Grossetete-Lalami S, Baulande S, Schleiermacher G, Barillot E, Rohrer H, Delattre O, JanoueixLerosey I (2017) Heterogeneity of neuroblastoma cell identity defined by transcriptional circuitries. Nat Genet 49(9):14081413. https://doi.org/10.1038/ng.3921

114. van Groningen T, Koster J, Valentijn LJ, Zwijnenburg DA, Akogul N, Hasselt NE, Broekmans M, Haneveld F, Nowakowska NE, Bras J, van Noesel CJM, Jongejan A, van Kampen AH, Koster L, Baas F, van Dijk-Kerkhoven L, Huizer-Smit M, Lecca MC, Chan A, Lakeman A, Molenaar P, Volckmann R, Westerhout EM, Hamdi M, van Sluis PG, Ebus ME, Molenaar JJ, Tytgat GA, Westerman BA, van Nes J, Versteeg R (2017) Neuroblastoma is composed of two super-enhancer-associated differentiation states. Nat Genet 49(8):1261-1266. https://doi. org/10.1038/ng.3899

115. van Groningen T, Akogul N, Westerhout EM, Chan A, Hasselt NE, Zwijnenburg DA, Broekmans M, Stroeken P, Haneveld F, Hooijer GKJ, Savci-Heijink CD, Lakeman A, Volckmann R, van Sluis P, Valentijn LJ, Koster J, Versteeg R, van Nes J (2019) A NOTCH feed-forward loop drives reprogramming from adrenergic to mesenchymal state in neuroblastoma. Nat Commun 10(1):1530. https://doi.org/10.1038/s41467-019-09470-w

116. Cimino PJ, Gutmann DH (2018) Neurofibromatosis type 1. Handbook of clinical neurology 148:799-811. https://doi.org/10.1016/ b978-0-444-64076-5.00051-x

117. Viskochil D, Buchberg AM, Xu G, Cawthon RM, Stevens J, Wolff RK, Culver M, Carey JC, Copeland NG, Jenkins NA et al (1990) Deletions and a translocation interrupt a cloned gene at the neurofibromatosis type 1 locus. Cell 62(1):187-192. https:// doi.org/10.1016/0092-8674(90)90252-a

118. Wallace MR, Marchuk DA, Andersen LB, Letcher R, Odeh HM, Saulino AM, Fountain JW, Brereton A, Nicholson J, Mitchell AL et al (1990) Type 1 neurofibromatosis gene: identification of a large transcript disrupted in three NF1 patients. Science 249(4965):181-186. https://doi.org/10.1126/science.2134734

119. Yang F-C, Ingram DA, Chen S, Zhu Y, Yuan J, Li X, Yang X, Knowles S, Horn W, Li Y, Zhang S, Yang Y, Vakili ST, Yu M, Burns D, Robertson K, Hutchins G, Parada LF, Clapp DW (2008)
Nf1-Dependent Tumors Require a Microenvironment Containing Nf1 \pm and c-kit-Dependent Bone Marrow. Cell 135(3):437-448. https://doi.org/10.1016/j.cell.2008.08.041

120. Wu J, Williams JP, Rizvi TA, Kordich JJ, Witte D, Meijer D, Stemmer-Rachamimov AO, Cancelas JA, Ratner N (2008) Plexiform and Dermal Neurofibromas and Pigmentation Are Caused by $<$ em $>$ Nf $1</$ em $>$ Loss in Desert Hedgehog-Expressing Cells. Cancer Cell 13(2):105-116. https://doi.org/10.1016/j. ccr.2007.12.027

121. Zheng H, Chang L, Patel N, Yang J, Lowe L, Burns DK, Zhu $Y$ (2008) Induction of abnormal proliferation by nonmyelinating schwann cells triggers neurofibroma formation. Cancer Cell 13(2):117-128. https://doi.org/10.1016/j.ccr.2008.01.002

122. Friedrich RE, Holstein AF, Middendorff R, Davidoff MS (2012) Vascular wall cells contribute to tumourigenesis in cutaneous neurofibromas of patients with neurofibromatosis type $1 \mathrm{~A}$ comparative histological, ultrastructural and immunohistochemical study. Anticancer Res 32(5):2139-2158

123. Yang FC, Ingram DA, Chen S, Hingtgen CM, Ratner N, Monk KR, Clegg T, White H, Mead L, Wenning MJ, Williams DA, Kapur R, Atkinson SJ, Clapp DW (2003) Neurofibromin-deficient Schwann cells secrete a potent migratory stimulus for $\mathrm{Nf1} \pm$ mast cells. J Clin Invest 112(12):1851-1861. https://doi. org/10.1172/jci19195

124. Kobayashi H, O'Briain DS, Puri P (1994) Nerve growth factor receptor immunostaining suggests an extrinsic origin for hypertrophic nerves in Hirschsprung's disease. J Gut 35(11):16051607. https://doi.org/10.1136/gut.35.11.1605

125. Wilkinson DJ, Bethell GS, Shukla R, Kenny SE, Edgar DH (2015) Isolation of enteric nervous system progenitor cells from the aganglionic gut of patients with Hirschsprung's Disease. PLoS ONE 10(5):e0125724. https://doi.org/10.1371/journ al.pone. 0125724

126. Burns AJ, Thapar N (2014) Neural stem cell therapies for enteric nervous system disorders. Nature Rev Gastroenterol Hepatol 11(5):317-328. https://doi.org/10.1038/nrgastro.2013.226

127. Laranjeira C, Sandgren K, Kessaris N, Richardson W, Potocnik A, Vanden Berghe P, Pachnis V (2011) Glial cells in the mouse enteric nervous system can undergo neurogenesis in response to injury. J Clin Investig 121(9):3412-3424. https:// doi.org/10.1172/JCI58200

128. Toy D, Namgung U (2013) Role of glial cells in axonal regeneration. Exp Neurobiol 22(2):68-76. https://doi.org/10.5607/ en.2013.22.2.68

Publisher's Note Springer Nature remains neutral with regard to jurisdictional claims in published maps and institutional affiliations. 